\title{
Review on Zinc Oxide Nanoparticles: Antibacterial Activity and Toxicity Mechanism
}

\author{
Amna Sirelkhatim • Shahrom Mahmud • Azman Seeni • \\ Noor Haida Mohamad Kaus • Ling Chuo Ann • Siti Khadijah Mohd Bakhori • \\ Habsah Hasan · Dasmawati Mohamad
}

Received: 31 January 2015/ Accepted: 11 March 2015/Published online: 19 April 2015

(C) The Author(s) 2015. This article is published with open access at Springerlink.com

\begin{abstract}
Antibacterial activity of zinc oxide nanoparticles (ZnO-NPs) has received significant interest worldwide particularly by the implementation of nanotechnology to synthesize particles in the nanometer region. Many microorganisms exist in the range from hundreds of nanometers to tens of micrometers. ZnO-NPs exhibit attractive antibacterial properties due to increased specific surface area as the reduced particle size leading to enhanced particle surface reactivity. $\mathrm{ZnO}$ is a bio-safe material that possesses photo-oxidizing and photocatalysis impacts on chemical and biological species. This review covered ZnO-NPs antibacterial activity including testing methods, impact of UV illumination, ZnO particle properties (size, concentration, morphology, and defects), particle surface modification, and minimum inhibitory concentration. Particular emphasize was given to bactericidal and bacteriostatic mechanisms with focus on generation of reactive oxygen species (ROS) including hydrogen peroxide $\left(\mathrm{H}_{2} \mathrm{O}_{2}\right), \mathrm{OH}^{-}$(hydroxyl radicals), and $\mathrm{O}_{2}^{-2}$ (peroxide). ROS has been a major factor for several mechanisms including cell wall damage due to $\mathrm{ZnO}$-localized interaction, enhanced membrane permeability, internalization of NPs due to loss of proton motive force and uptake of toxic dissolved zinc ions. These have led to mitochondria weakness, intracellular outflow, and release in gene expression of oxidative stress which caused eventual cell growth inhibition and cell death. In some cases, enhanced antibacterial activity can be attributed to surface defects on $\mathrm{ZnO}$ abrasive surface texture. One functional application of the $\mathrm{ZnO}$ antibacterial bioactivity was discussed in food packaging industry where $\mathrm{ZnO}-\mathrm{NPs}$ are used as an antibacterial agent toward foodborne diseases. Proper incorporation of $\mathrm{ZnO}-\mathrm{NPs}$ into packaging materials can cause interaction with foodborne pathogens, thereby releasing NPs onto food surface where they come in contact with bad bacteria and cause the bacterial death and/or inhibition.
\end{abstract}

Keywords Antibacterial activity $\cdot \mathrm{ZnO}-\mathrm{NPs} \cdot$ Toxicity mechanism $\cdot$ Reactive oxygen species $\cdot$ Zinc ions release $\cdot$ Food antimicrobial

A. Sirelkhatim $(\bowtie) \cdot$ S. Mahmud · L. C. Ann .

S. K. M. Bakhori

Nano-Optoelectronics Research and Technology Laboratory (N.O.R. Lab), School of Physics, Universiti Sains Malaysia, 11800 Minden, Pulau Pinang, Malaysia

e-mail: amnasirelkhatim@yahoo.co.uk

A. Seeni

Advanced Medical and Dental Institute, Cluster of Integrative

Medicine, Universiti Sains Malaysia, 13200 Bertam, Malaysia

N. H. M. Kaus

School of Chemical Sciences, Universiti Sains Malaysia,

11800 Minden, Pulau Pinang, Malaysia
H. Hasan

Department of Medical Microbiology, Parasitology and Immunology, School of Medical Sciences, Universiti Sains Malaysia, Kubang Kerian, 16150 Kubang Kerian, Kelantan, Malaysia

D. Mohamad

School of Dental Sciences, Universiti Sains Malaysia, 16150 Kubang Kerian, Kelantan, Malaysia 


$\begin{array}{ll}\text { Abbreviations } \\ \text { ROS } & \text { Reactive oxygen species } \\ \text { MIC } & \text { The minimum inhibitory concentration } \\ \text { MBC } & \text { Minimum bactericidal concentration } \\ \text { XRD } & \text { X-ray diffraction } \\ \text { FESEM } & \text { Field emission scanning electron microscope } \\ \text { TEM } & \text { Transmission electron microscope } \\ \text { EDX } & \text { Energy dispersive X-ray spectroscopy } \\ \text { ESI } & \text { Electron spectroscopy imaging, by energy- } \\ & \text { filtered transmission electron microscopy } \\ & \text { (EFTEM) } \\ \text { IV } & \text { Current-voltage measurement } \\ \text { ATCC } & \text { American Association of Textile Chemists and } \\ & \text { Colorists } \\ \text { NA } & \text { Nutrient agar } \\ \text { LB } & \text { Luria-Bertani broth } \\ \text { TSB } & \text { Trypticase soy broth } \\ \text { TSA } & \text { Tryptic soy agar } \\ \text { BA } & \text { Blood agar } \\ \text { CFU } & \text { Colony forming unit } \\ \text { PEG } & \text { Polyethylene glycol } \\ \text { PVP } & \text { Polyvinylpyrrolidone } \\ \text { PGA } & \text { Poly } \alpha, \gamma, \text { L-glutamic acid) }\end{array}$

\section{Introduction}

Nanotechnology is a research hot spot in modern materials science. This technology is capable of providing miscellaneous novel applications that range from innovative fabric compounds, food processing, and agricultural production to sophisticated medicinal techniques [1]. It is considered as the synthesis, characterization, and exploration of materials in the nanometer region $(1-100 \mathrm{~nm})$. At this level, the properties and functions of living and anthropogenic systems are defined [2]. In this technology, the pertinent materials are those whose structures exhibit new and considerably enhanced physicochemical and biological properties as well as distinct phenomena and functionalities as a result of the nanoscale size [3]. This nanoscale size generally confers larger surface areas to nanoparticles (NPs) compared with macro-sized particles [4]. NPs are known as controlled or manipulated particles at the atomic level $(1-100 \mathrm{~nm})$. They show size-related properties significantly different from bulk materials [5]. Given their small size, NPs have larger structures in comparison with their counterparts. This distinct property allows their possible applications in many fields such as biosensors, nanomedicine, and bionanotechnology [4]. The intrinsic properties of metal NPs such as zinc oxide $(\mathrm{ZnO}), \mathrm{TiO}_{2}$, and silver are mostly characterized by their size, composition, crystallinity, and morphology. Reducing the size to nanoscale can modify their chemical, mechanical, electrical, structural, morphological, and optical properties. These modified features allow the NPs to interact in a unique manner with cell biomolecules and thus facilitate the physical transfer of NPs into the inner cellular structures [6]. Nanostructured materials have a larger percentage of atoms at their surface which lead to high surface reactivity. Thus, nanomaterials have witnessed recently significant importance in the basic and applied sciences as well as in bionanotechnology.

Nano-sized $\mathrm{ZnO}$ exhibits varying morphologies and shows significant antibacterial activity over a wide spectrum of bacterial species explored by a large body of researchers [5, 7-13]. $\mathrm{ZnO}$ is currently being investigated as an antibacterial agent in both microscale and nanoscale formulations. $\mathrm{ZnO}$ exhibits significant antimicrobial activities when particle size is reduced to the nanometer range, then nano-sized $\mathrm{ZnO}$ can interact with bacterial surface and/or with the bacterial core where it enters inside the cell, and subsequently exhibits distinct bactericidal mechanisms [10]. The interactions between these unique materials and bacteria are mostly toxic, which have been exploited for antimicrobial applications such as in food industry.

Interestingly, $\mathrm{ZnO}-\mathrm{NPs}$ are reported by several studies as non-toxic to human cells [14], this aspect necessitated their usage as antibacterial agents, noxious to microorganisms, and hold good biocompatibility to human cells [12]. The various antibacterial mechanisms of nanomaterials are mostly attributed to their high specific surface area-to-volume ratios [15], and their distinctive physicochemical properties. However, the precise mechanisms are yet under debate, although several proposed ones are suggested and adopted. Investigations on antibacterial nanomaterials, mostly ZnO-NPs, would enhance the research area of nanomaterials, and the mechanisms and phenomenon behind nanostructured materials.

Bacterial infectious diseases are serious health problem that has drawn the public attention in worldwide as a human health threat, which extends to economic and social complications. Increased outbreaks and infections of pathogenic strains, bacterial antibiotic resistance, emergence of new bacterial mutations, lack of suitable vaccine in underdeveloped countries, and hospital-associated infections, are global health hazard to human, particularly in children. For example, infections by Shigella flexneri cause 1.5 million deaths annually, due to contaminated food and drinks by these bacteria [16]. Thus, developing novel antibacterial agents against bacteria strains, mostly major food pathogens, such as Escherichia coli $\mathrm{O} 157: \mathrm{H}$, Campylobacter jejuni, Staphylococcus aureus, Pseudomonas aeruginosa, Enterococcus faecalis, Salmonella 
types, and Clostridium perfringens, has become utmost demand. This work is intended to explore these problems to induce further investigations in these areas by addressing new techniques, benefiting from the unique features of $\mathrm{ZnO}-\mathrm{NPs}$, and from to date successful studies.

In this paper, we have extensively reviewed ideas behind the antibacterial activity of $\mathrm{ZnO}-\mathrm{NPs}$ covering techniques of evaluating bacteria viability. In the subsequent sections, we have discussed the factors affecting the antibacterial activity, including UV illumination, ZnO particle size, concentration, morphology, surface modifications by annealing, surface defects, and the minimum inhibitory concentration (MIC) and minimum bactericidal concentration (MBC). A brief presentation of an experimental case study, carried by authors on antibacterial activity response to $E$. coli, was explored. A special focus has been given on a range of remarkable toxicity mechanisms that underlie this bacterial activity, mainly reactive oxygen species (ROS) generation and $\mathrm{Zn}^{2+}$ release. Finally, a concise discussion was made to an essential application of ZnO-NPs antibacterial activity as an antimicrobial agent against foodborne diseases and food packaging.

\section{Zinc Oxide Nanoparticles}

$\mathrm{ZnO}$ is described as a functional, strategic, promising, and versatile inorganic material with a broad range of applications. It is known as II-VI semiconductor [17], since Zn and $\mathrm{O}$ are classified into groups two and six in the periodic table, respectively. ZnO holds a unique optical, chemical sensing, semiconducting, electric conductivity, and piezoelectric properties [18]. It is characterized by a direct wide band gap $(3.3 \mathrm{eV})$ in the near-UV spectrum, a high excitonic binding energy $(60 \mathrm{meV})$ at room temperature [19-23], and a natural n-type electrical conductivity [24]. These characteristics enable $\mathrm{ZnO}$ to have remarkable applications in diverse fields [20]. The wide band gap of $\mathrm{ZnO}$ has significant effect on its properties, such as the electrical conductivity and optical absorption. The excitonic emission can persevere higher at room temperature [21] and the conductivity increases when $\mathrm{ZnO}$ doped with other metals [19]. Though $\mathrm{ZnO}$ shows light covalent character, it has very strong ionic bonding in the $\mathrm{Zn}-\mathrm{O}$. Its longer durability, higher selectivity, and heat resistance are preceded than organic and inorganic materials [12]. The synthesis of nano-sized $\mathrm{ZnO}$ has led to the investigation of its use as new antibacterial agent. In addition to its unique antibacterial and antifungal properties, ZnO-NPs possess high catalytic and high photochemical activities. $\mathrm{ZnO}$ possesses high optical absorption in the UVA (315-400 nm) and UVB $(280-315 \mathrm{~nm})$ regions which is beneficial in antibacterial response and used as a UV protector in cosmetics [25].

\subsection{Synthesis of $\mathrm{ZnO}$ Nanostructures}

$\mathrm{ZnO}$ nanostructures have been a subject of immense research owing to their multifunctional properties in diverse applications. The nanostructured $\mathrm{ZnO}$ has been emerged as a potential candidate for applications in sensors, energy harvesting, and many electronic devices. Many pronounced applications are being currently explored in the biomedical and antiviral areas. This is as a result of their potential biocompatibility over other metal oxides, solubility in alkaline medium, and the $\mathrm{Zn}-\mathrm{O}$ terminated polar surfaces [26]. The unique properties and versatility of $\mathrm{ZnO}$ pave the way to use various methods to synthesize various $\mathrm{ZnO}$ nanostructures. ZnO-NPs can be synthesized through various methods by controlling the synthesis parameters. The properties can be tailored by shape and size, resulting in renewable applications relevant to their structural properties. Mostly, the selected method depends on the desired application, as different methods produce different morphologies and also different sizes of $\mathrm{ZnO}$ particles. Accordingly, the chemical and physical parameters such as the solvent type, precursors, $\mathrm{pH}$, and the temperature were highly considered. An assortment of $\mathrm{ZnO}$ nanostructures with different growth morphologies such as nanorods, nanosphere, nanotubes, nanowires, nanoneedles and nanorings have been successfully synthesized [27]. Such unique $\mathrm{ZnO}$ nanostructures reflected the richest nanoconfiguration assembly compared to other nano-metal oxides, in terms of properties and structure, such as nanobelts, nanocages, nanocombs and nanosprings/nanohelixes [19]. Other shapes can also be obtained, such as $\mathrm{ZnO}$ spirals, drums, polyhedrons, disks, flowers, stars, boxes, and plates [28], those are possibly grown by adjusting the growth conditions. Each nanostructure has specific structural, optical, electrical, and physicochemical properties [29], permitting remarkable applications. These nanostructures have been fabricated using variety of physical and chemical techniques; however, the chemical techniques allow better control of the particle size and morphology [30]. The most adopted fabrication methods include thermal evaporation of $\mathrm{ZnO}$ powders at $1400{ }^{\circ} \mathrm{C}$, hydrothermal synthesis, solgel technique, simple thermal sublimation, self-combustion, polymerized complex method, vapor-liquid-solid technique, double-jet precipitation, and solution synthesis [27, 31]. The solution process was used by several researchers to produce selective $\mathrm{ZnO}$ nanostructures. Wahab et al. [32] have synthesized flower-shaped $\mathrm{ZnO}$ nanostructures which were produced via solution process at low temperature $\left(90^{\circ} \mathrm{C}\right)$ using the zinc acetate dihydrate and $\mathrm{NaOH}$. As well, Zhang et al. [33] have synthesized the 
flower-shaped, prism, snowflakes, and rod-like morphologies $\mathrm{ZnO}$, at a high temperature of $180{ }^{\circ} \mathrm{C}$ for $13 \mathrm{~h}$. The researchers also prepared prism-like and prickly spherelike $\mathrm{ZnO}$ via decomposition process at $100{ }^{\circ} \mathrm{C}$ for $13 \mathrm{~h}$. These nanostructures plus others such as nanowires, nanoplates, and nanorods have been key factors for the antibacterial activity, as each morphology accounts for a certain mechanism of action. Thus, a large number of researchers have been motivated to achieve selective nanostructured $\mathrm{ZnO}$ for the antibacterial tests. They succeeded to produce morphologies that were highly compatible with the antibacterial activity. Wahab et al. [34] carried a non-hydrolytic solution process using zinc acetate dihydrate to prepare $\mathrm{ZnO}$-NPs. The method yielded structures of spherical surface that showed high antibacterial activity against the tested pathogens. Similarly, spherical shaped ZnO-NPs in another investigation [35] were obtained via soft chemical solution process, and it was used for the treatment of bacteria (E. coli, S. aureus, P. aeruginosa, B. subtilis, and S. acidaminiphila) and cancer cells (HepG2 and MCF-7 cell lines). While Stanković et al. [36] have synthesized $\mathrm{ZnO}$ powder hydrothermally with the addition of different stabilizing agents leading to different nanostructures. The obtained synthesized $\mathrm{ZnO}$ has shown nanorods of hexagonal prismatic and hexagonal pyramidlike structures, with some spherical and ellipsoid shapes. These different morphologies displayed pronounced antibacterial effect toward the targeted bacteria. Further discussions are in Sect. 4.2 coupled with Table 1 displaying some synthesis methods and their corresponding morphology of $\mathrm{ZnO}$.

In a more recent study [37], $\mathrm{ZnO}$ nanowires were synthesized in heterojunction of silver-loaded $\mathrm{ZnO}\left(\mathrm{Ag}_{x} \mathrm{Zn}_{1-x} \mathrm{O}-\right.$ $\mathrm{ZnO}$ nanowires) through $\mathrm{UV}$ light decomposition process. It was found to exhibit higher antibacterial activities to $E$. coli under visible light or in the dark. It disrupted the bacterial membrane and released lethal active species.

Techniques of doping and implanting foreign metals on $\mathrm{ZnO}$ nanostructures to develop functional antibacterial agent have become a topic among researchers. Doped and undoped $\mathrm{ZnO}$ of nanosphere and nanorod shapes were synthesized by simple wet chemical technique, and were annealed at $600{ }^{\circ} \mathrm{C}$ for $2 \mathrm{~h} \mathrm{[38].} \mathrm{The} \mathrm{resultant} \mathrm{ZnO}$ samples were tested against three bacterial strains (E. coli, P. aeruginosa, and $S$. aureus). ZnO-doped samples exhibited considerably high activity toward S. aureus (skin bacteria) in comparison to $E$. coli and $P$. aeruginosa. It produced zone of inhibition of $4 \%$ which was $37 \%$ higher than that produced by undoped $\mathrm{ZnO}$ nanostructures. These results were beneficial for medical application. S. aureus is well known of causing contamination in hospital implants leading to serious infections [39]. $\mathrm{ZnO}$ is characterized by its antibacterial coatings, incorporation in skin creams, and UV protection. Therefore, coating hospital implants with $4 \%$ of this doped $\mathrm{ZnO}$ nanostructures will be more effective in controlling associated bacterial infections. On the other hand, such doped $\mathrm{ZnO}$ can alternatively be used in skin lotions and in UV protection than undoped $\mathrm{ZnO}$.

Usually, antibacterial tests are done in aqueous media or cell culture media. $\mathrm{ZnO}$ is known as nearly insoluble in water, it agglomerates immediately with water during synthesis due to the high polarity of water leading to deposition. Issues of aggregation, re-precipitation, settling, or non-dissolution impede the synthesis processes. In this regards, a number of researchers considered this difficulty by using certain additives that have no significant effect in the antibacterial activity. As such, in the above mentioned study [36], the addition of PVA, polyvinylpyrrolidone (PVP), and poly ( $\alpha, \gamma, \mathrm{L}$-glutamic acid) (PGA; see Abbreviations) as stabilizers enhanced $\mathrm{ZnO}$ morphology and size for the antibacterial activity. Meanwhile, Zhang et al. have addressed the problem by adding dispersants polyethylene glycol (PEG; see Abbreviations) and PVP (10\% of the amount of $\mathrm{ZnO}-\mathrm{NPs}$ ) which enhanced the stability of $\mathrm{ZnO}$ and resulted in $\mathrm{ZnO}$ nanofluids, well suited for the antibacterial tests. While other researchers used appropriate capping agents [12] or deflocculants (sodium silicate $\mathrm{Na}_{2}$ $\mathrm{SiO}_{3}$ or sodium carbonate $\mathrm{Na}_{2} \mathrm{CO}_{3}$ ). After addition, the mixtures were exposed to vigorous vortex (e.g., $5 \mathrm{~min}$ ) or kept overnight on magnetic stirring and then ultrasonicated

Table $1 \mathrm{ZnO}$ synthesis and resultant morphology

\begin{tabular}{|c|c|c|}
\hline Techniques & $\mathrm{ZnO}$ morphology & References \\
\hline Microwave decomposition & Sphere & Jalal et al. [9] \\
\hline Simple wet chemical route & Nano and micro-flowers, dumbbell shaped, rice flakes, and rings & Ramani et al. [129] \\
\hline Deposition process & Dumbbell- and rod-shaped $\mathrm{ZnO}$ & \\
\hline Simple precipitation method & Nano-flakes & Kumar et al. [146] \\
\hline Hydrothermal synthesis & Hexagonal prismatic rods & Stanković et al. [36] \\
\hline Solvothermal method & Nano-flowers, nanorods, nano-spheres & Talebian et al. [77] \\
\hline Microwave hydrothermal method & Mulberry-like & Ma et al. [78] \\
\hline Hydrothermal technique & Nanorods & Hafez et al. [147] \\
\hline
\end{tabular}


20-30 min to avoid aggregation and deposition of particles. Characterization of ZnO-NPs is required to identify factors impacted stability such as particle size, $\mathrm{pH}$ solution, structural, morphological, and surface properties, these factors in turn have effect on the bioactivity.

\subsection{Crystal Structure of $\mathrm{ZnO}$}

$\mathrm{ZnO}$ exhibits three crystallize structures namely, wurtzite, zinc-blende and an occasionally noticed rock-salt [41, 42]. The hexagonal wurtzite structure possesses lattice spacing $a=0.325 \mathrm{~nm}$ and $c=0.521 \mathrm{~nm}$, the ratio $c / a \sim 1.6$ that is very close to the ideal value for hexagonal cell $c /$ $a=1.633$. Each tetrahedral $\mathrm{Zn}$ atom is surrounded by four oxygen atoms and vice versa [43]. The structure is thermodynamically stable in an ambient environment [42], and usually illustrated schematically as a number of alternating planes of $\mathrm{Zn}$ and $\mathrm{O}$ ions stacked alongside the $c$-axis. Zincblende structure is metastable and can be stabilized via growth techniques. These crystal structures are illustrated in (Fig. 1a), and the black and gray-shaded spheres symbolize $\mathrm{O}$ and $\mathrm{Zn}$ atoms, respectively.

\section{Antibacterial Activity of $\mathrm{ZnO}$ Nanoparticles}

Bacteria are generally characterized by a cell membrane, cell wall, and cytoplasm. The cell wall lies outside the cell membrane and is composed mostly of a homogeneous peptidoglycan layer (which consists of amino acids and sugars). The cell wall maintains the osmotic pressure of the cytoplasm as well the characteristic cell shape. Grampositive bacteria have one cytoplasmic membrane with multilayer of peptidoglycan polymer [44], and a thicker cell wall $(20-80 \mathrm{~nm})$. Whereas gram-negative bacteria wall is composed of two cell membranes, an outer membrane and a plasma membrane with a thin layer of peptidoglycan [44] with a thickness of 7-8 nm. NPs size within such ranges can readily pass through the peptidoglycan and hence are highly susceptible to damage. The cytoplasm, a jelly-like fluid that fills a cell, involves all the cellular components except the nucleus. The functions of this organelle include growth, metabolism, and replication. Consequently, the cytoplasm contains proteins, carbohydrates, nucleic acids, salts, ions, and water $(\sim 80 \%)$. This composition contributes in the electrical conductivity of the cellular structure. The overall charge of bacterial cell walls is negative. Figure $1 \mathrm{~b}$ shows typical bacteria cell structures [45]. Antibacterial activity is known according to The American Heritage Medical Dictionary 2007, as the action by which bacterial growth is destroyed or inhibited. It is also described as a function of the surface area in contact with the microorganisms [46]. While antibacterial agents are selective concentration drugs capable to damage or inhibit bacterial growth and they are not harmful to the host. These compounds act as chemo-therapeutic agents for the treatment or prevention of bacterial infections (Saunders Comprehensive Veterinary Dictionary 2007). An

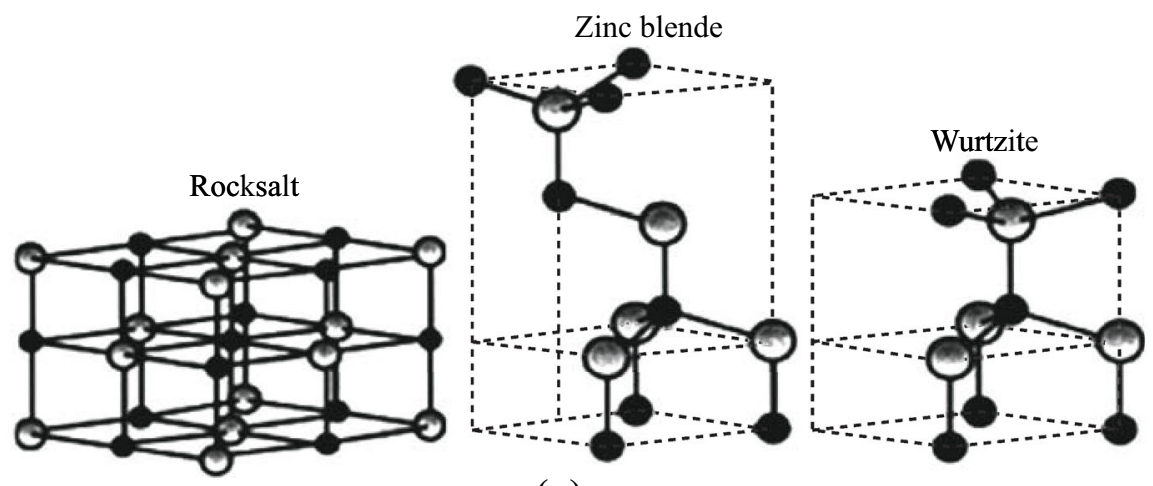

(a)

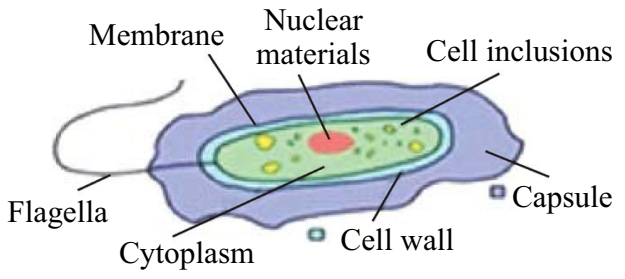

(b)

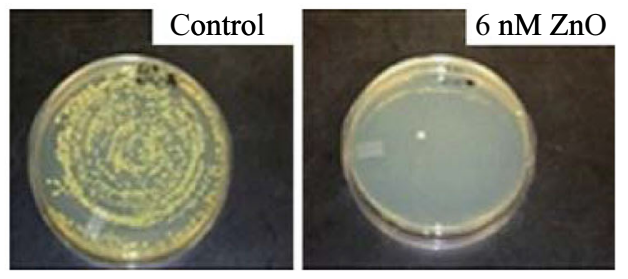

(c)

Fig. 1 a $\mathrm{ZnO}$ crystal structures. Adapted from Ozgur et al. [41]. b Bacterial cell structures, reused from Earth Doctor, Inc., formerly AlkenMurray [45]. c S. aureus plating for colony count [13] 


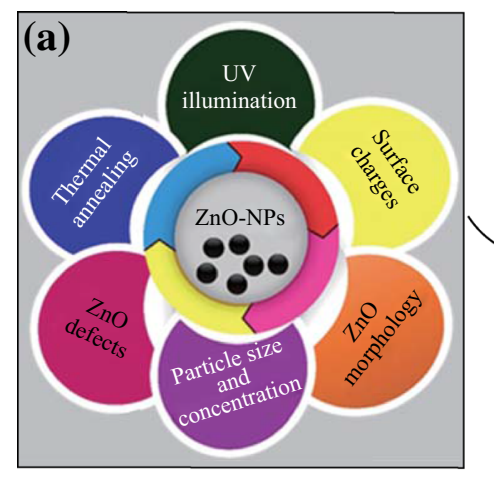

(b)

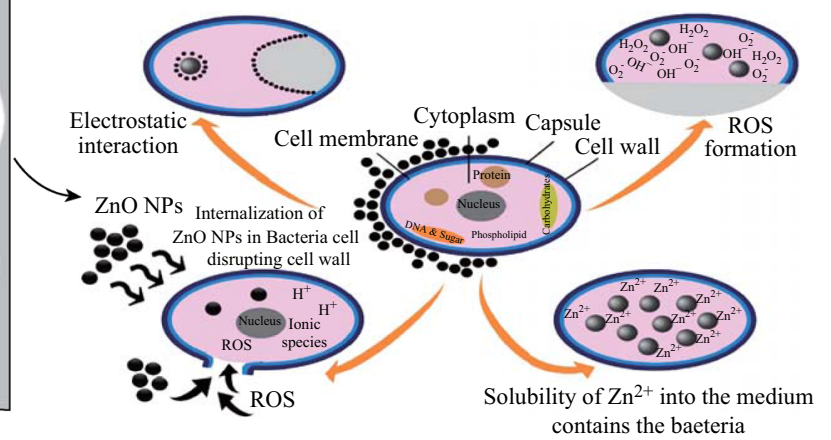

Fig. 2 Correlation between the a influence of essential ZnO-NPs parameters on the antibacterial response and the b different possible mechanisms of $\mathrm{ZnO}-\mathrm{NPs}$ antibacterial activity, including: ROS formation, $\mathrm{Zn}^{2+}$ release, internalization of $\mathrm{ZnO}-\mathrm{NPs}$ into bacteria, and electrostatic interactions

antibacterial agent is considered as bactericidal if it kills bacteria or as bacteriostatic if it inhibits their growth.

Different methods have been adopted for the assessment and investigation of antibacterial activity in vitro. These methods include disk diffusion, broth dilution, agar dilution, and the microtiter plate-based method [47]. Other methods are different according to the investigated parameters. For example, the conductometric assay measures the bacterial metabolism-induced alterations in the electrical conductivity of growth media [48, 49]. Meanwhile, Reddy et al. [50] have used the flow cytometry viability assays to examine ZnO-NPs toxicity toward E. coli and $S$. aureus. The most commonly used method is the broth dilution method, followed by colony count, through plating serial culture broths dilutions which contained $\mathrm{ZnO}-\mathrm{NPs}$ and the targeted bacteria in appropriate agar medium and incubated. A number of researchers [13] have examined the antibacterial activity of $\mathrm{ZnO}-\mathrm{NPs}$ to determine bacterial growth through the culture turbidity and the viable cells percentage by the colony counts test (Fig. 1c). While others, such as Yamamoto [51] enhanced the antibacterial activity of $\mathrm{ZnO}-\mathrm{NPs}$ by modulating within the procedure. They considered that the antibacterial activity rate was much improved by decreasing the initial number of bacterial cells from $10^{2}$ to $10^{6}$ colony forming unit (CFU). Nair et al. [52] considered that the determination of starting number of bacterial cells is very important in the antibacterial activity evaluation. The MIC of an antimicrobial agent and MBC can be measured by using the susceptibility test methods. However, there are some variations in the established laboratory methods and protocols in the assessment of the bactericidal activity [53]. The agar diffusion method (an indirect method) is the most frequently used method and has been standardized as an official method for detecting bacteriostatic activity by the (ATCC). Other direct test methods, such as the measurement of urease inhibition of inocula, have been reported [54]. The microdilution method is a modification of the broth macrodilution test, which utilizes the advances in miniaturization to allow multiple tests to be performed on a 96-well plate. Modified procedures along with the standard methods are also used by a large body of researchers. In all of the aforementioned methods, the culture media [trypticase soy broth (TSB), Luria-Bertani broth (LB), nutrient agar (NA), tryptic soy agar (TSA), and blood agar (BA; see Abbreviations)] were accordingly selected to autoclave and stored at $4-5{ }^{\circ} \mathrm{C}$. The stocks of ZnO-NPs suspensions are also usually prepared, and serially diluted to different concentrations, and then characterized using techniques [X-ray diffraction (XRD), field emission scanning electron microscope (FESEM), transmission electron microscope (TEM), energy dispersive X-ray spectroscopy (EDX), electron spectroscopy imaging (ESI), etc.; see Abbreviations] to correlate the antibacterial response with $\mathrm{ZnO}$ properties.

Growth curves were typically obtained via monitoring the optical density (OD), at wavelength of $600 \mathrm{~nm}$, a typical wavelength for cells. The density of bacterial isolates must be adjusted to an optimal density of 0.5 McFarland standards. The OD should serially be monitored hourly up to $12 \mathrm{~h}$ of incubation, and finally after $24 \mathrm{~h}$ of overnight incubation for the determination of the percentage of growth inhibition [8]. The inhibition rate varies with the tested organisms and the utilized NP-oxide [55].

We discuss below the influence of essential physiochemical and structural factors (Fig. 2a), which affect the antibacterial activity of ZnO-NPs, and consequently have potential impact upon the resultant toxicity mechanism (Fig. 2b).

\section{Mechanism of Antibacterial Activity of ZnO-NPs}

Researchers analyzing morphological bacterial changes are induced by $\mathrm{ZnO}$ using SEM or FESEM to quantify the 
multiple mechanisms. Though, the antibacterial activity of $\mathrm{ZnO}-\mathrm{NPs}$ has been referred to a number of issues, but the exact toxicity mechanism is not completely illuminated and still controversial, as there are some queries within the spectrum of antibacterial activity requiring deep explanations. Distinctive mechanisms that have been put forward in the literature are listed as following: direct contact of ZnO-NPs with cell walls, resulting in destructing bacterial cell integrity [7, 40, 56], liberation of antimicrobial ions mainly $\mathrm{Zn}^{2+}$ ions [57-59], and ROS formation [9, 60-62]. However, the toxicity mechanism varies in various media as the species of dissolved $\mathrm{Zn}$ may change according to the medium components besides the physicochemical properties of $\mathrm{ZnO}-\mathrm{NPs}$ [59].

\subsection{UV Illumination Effect}

$\mathrm{ZnO}$ is found to possess high photocatalytic efficiency among all inorganic photocatalytic materials, and is more biocompatible than $\mathrm{TiO}_{2}$ [63]. ZnO can highly absorb UV light [64], and it has a better response to UV light, thus its conductivity dramatically enhances, and this feature significantly activates the interaction of $\mathrm{ZnO}$ with bacteria. Its photoconductivity persists long after turning off the UV light, and it has been attributed to surface electron depletion region strongly associated to negative oxygen species $\left(\mathrm{O}_{2}^{-}, \mathrm{O}_{2}^{2-}\right)$, adsorbed on the surface [65]. UV illumination rapidly causes desorption of this loosely bound oxygen from the surface. This results in reducing the surface electron depletion region and causing improved photoconductivity [66]. The photocatalysis is described as a photo-induced oxidation process that can damage and inactivate organisms [67]. ZnO-NPs in aqueous solution under UV radiation have phototoxic effect that can produce ROS such as hydrogen peroxide $\left(\mathrm{H}_{2} \mathrm{O}_{2}\right)$ and superoxide ions $\left(\mathrm{O}^{2-}\right)$. Such species are extremely essential for bioapplications [68]. The generated active species are capable to penetrate into the cells, thus inhibit or kill microorganisms. This process inspired the use of the photocatalytic activity of $\mathrm{ZnO}-\mathrm{NPs}$ in bionanotechnology and in bionanomedicine for many antibacterial applications. Therefore, enhancement of $\mathrm{ZnO}$ bioactivity was considered as a result of the produced free radicals, as $\mathrm{ZnO}$ absorbs UV light [15]. A detailed reaction mechanism which explains this phenomenon was proposed by Seven et al. [69] and Padmavathy and Vijayaraghavan [12] as follows.

The electronic band structure of $\mathrm{ZnO}$, as a semiconductor material consists of a conduction band (CB) and a valence band (VB). Incident radiation with photons of energy greater than $3.3 \mathrm{eV}$ is immediately absorbed, thus the electrons move from the VB to the $\mathrm{CB}$. This electron transfer initiates a series of possible photoreactions. As a result, positive holes $\left(\mathrm{h}^{+}\right)$are formed in the VB, while free electrons are created within the CB [69-71]. This positive hole $\left(\mathrm{h}^{+}\right)$, a direct oxidant and essential for the creation of reactive hydroxyl radicals $\left(\mathrm{OH}^{\bullet}\right)$, serves as principal oxidants in the photocatalytic system [22, 70]. The electrons in the $\mathrm{CB}$ reduce oxygen, which is adsorbed by the photocatalyst [22]. Meanwhile, Padmavathy et al. proposed an association between photon reaction and the antibacterial activity in a series of reactions resulting in production of hydrogen peroxide $\left(\mathrm{H}_{2} \mathrm{O}_{2}\right)$ molecules which penetrates the membrane, causing fatal damage. Sawai et al. [60] also attributed the disruption of the cell membrane to peroxidation of the unsaturated phospholipids as a result of photocatalytic prompted $\mathrm{H}_{2} \mathrm{O}_{2}$.

In antibacterial tests that involve UV exposure, OD readings are taken before and after UV illumination. Shorter exposures $(15 \mathrm{~min})$ result in significantly few colonies, while many colonies could be detected and counted by long exposure times (up to $30 \mathrm{~min}$ ). Generally, it has been observed from the intensive studies held, that the antibacterial activity of $\mathrm{ZnO}$ can be verified under UV light as well as in the dark to inhibit the bacterial growth. Zhou et al. [72] reported best results of antibacterial effects upon UV exposure toward E. coli and S. aureus, which were 98.65 and $99.45 \%$ under UV, respectively. The authors referred that to $\mathrm{OH}$ production under light, and they produced a novel $\mathrm{ZnO}$ complex. Their findings also showed that the activity can be achieved under UV illumination, ambient light, or even in the dark. However, $\mathrm{ZnO}$ exhibits considerable activity against bacteria under different test conditions [8, 56, 73] and fungi [61]. Besides, the active species that drive the activity can be created without UV irradiation [61, 74]. We have also carried a study [75] for the antibacterial activity toward E. coli and $S$. aureus using $\mathrm{ZnO}$ of two forms ( $\mathrm{ZnO}$-rod and $\mathrm{ZnO}$ plate) which are exposed to UVA illumination $(390 \mathrm{~nm}$, $1.8 \mathrm{~W} \mathrm{~cm}^{-2}$ ). We found that UVA illumination had significantly influenced the interaction of both $\mathrm{ZnO}$ samples with the targeted bacteria compared with unexposed $\mathrm{ZnO}$. Exposure of only $20 \mathrm{~min}$ increased the inhibition of E. coli by $18 \%$ (ZnO-rod) and $13 \%$ ( $\mathrm{ZnO}$-plate), whereas, for $S$. aureus, $22 \%$ increase for treated with $\mathrm{ZnO}$-rod and $21 \%$ with ZnO-plate, compared with the unexposed. Thus, longer durations of UVA exposure expected to lead to greater growth inhibition. To elucidate the effects of oxygen species on antibacterial response, electrical, structural, and optical characterization of $\mathrm{ZnO}$ were performed. For example, the result of the current-voltage measurements (IV) showed significant increase in surface conductance (7fold for $\mathrm{ZnO}$-rod and 5-fold for $\mathrm{ZnO}$-plate) due to a decrease in the depletion layer upon UVA illumination. It was suggested that photo-excitation caused desorption of the oxygen molecules from the surface, thus the surface potential decreased and underlying photoconductivity of 
$\mathrm{ZnO}$. Stimulation of oxygen species such as $\mathrm{H}_{2} \mathrm{O}_{2}, \mathrm{O}_{2}^{-}$and $\mathrm{OH}^{\bullet}$ by UV light found to harm bacteria and damage the active enzyme, DNA, and protein [74, 76]. Our results were in consistence with Raghupathi et al. [13], whose results also revealed high antibacterial activity upon UV illumination.

\subsection{Impact of $\mathrm{ZnO}$ Morphology}

The impact of $\mathrm{ZnO}$ shapes has attracted current research [3]. Many studies have reported that the toxicity is significantly affected by the various morphologies of $\mathrm{ZnO}$ NPs [36, 77, 78]. ZnO morphology is determined by the synthesis conditions as mentioned earlier. Thus, desired synthesized ZnO-NPs structures for best antibacterial response could be attained by controlling parameters such as solvents, precursor types, and physicochemical settings such as temperature and $\mathrm{pH}$ [71] as well as shape-directing agents. Also, under controlled growth conditions, the surface morphology is determined by the surface activity.

The shape-dependent activity was explained in terms of the percent of active facets in the NPs. Synthesis and growth techniques lead to holding numerous active facets in NP. Rod-structures of $\mathrm{ZnO}$ have (111) and (100) facets, whereas spherical nanostructures mainly have (100) facets. High-atom-density facets with (111) facets exhibit higher antibacterial activity [3]. The facet-dependent $\mathrm{ZnO}$ antibacterial activity has been evaluated by few studies, and nanostructured $\mathrm{ZnO}$ with different morphologies have different active facets, which may lead to enhanced antibacterial activity [79]. In this regard, the shape of $\mathrm{ZnO}$ nanostructures can influence their mechanism of internalization such as rods and wires penetrating into cell walls of bacteria more easily than spherical $\mathrm{ZnO}-\mathrm{NPs}$ [80]. Whereas, flower-shaped have revealed higher biocidal activity against $S$. aureus, and $E$. coli than the spherical and rod-shaped ZnO-NPs [77]. In addition to the enhancement of internalization, it has been suggested regarding the contribution of the polar facets of $\mathrm{ZnO}$ nanostructured to the antibacterial activity, that the higher number of polar surfaces possess higher amount of oxygen vacancies. Oxygen vacancies are known to increase the generation of $\mathrm{ROS}$ and consequently affect the photocatalytic of $\mathrm{ZnO}$ [81]. Currently, it has been found that greater antibacterial results could be achieved from $\mathrm{ZnO}$ morphologies of highly exposed $\left(\begin{array}{llll}0 & 0 & 0 & 1\end{array}\right)$-Zn terminated polar facets [82].

\subsection{Surface Modification by Thermal Annealing}

Functionalized $\mathrm{ZnO}$ surface leads to best antibacterial responses. Annealing of $\mathrm{ZnO}$ powder has much effect in increasing the inhibition. In our study [75], the EDX and IV measurements revealed that oxygen annealing increased the amount of oxygen atoms on the surface of $\mathrm{ZnO}$ samples. Oxygen annealing stimulated a high amount of oxygen atoms to be absorbed onto $\mathrm{ZnO}$ surface, thereby enhanced antibacterial response inducing more ROS in the suspension resulting in intense oxidative stress towards the bacteria. This was also in agreement with our study [83] that used ESI method to explore the zinc and oxygen atoms on $\mathrm{ZnO}$ structure, and it has shown a considerable increase of O:Zn ratio of the oxygen annealed samples. Modifying $\mathrm{ZnO}$-NPs surface area would establish the release of $\mathrm{Zn}^{2+}$ ions and enhance ROS production. Mamat et al. [84] increased the surface area of $\mathrm{ZnO}$ nanorods by annealing under oxygen and air to stimulate formation of nanoholes on the surface to increase the surface area, and on turn have caused high absorption and diffusion of oxygen molecules onto the surface upon UV light exposure, which consequently assisted in generating more ROS on the surface.

$\mathrm{O}_{2}(\mathrm{~g})+\mathrm{e}^{-}=\mathrm{O}_{2}^{-}(\mathrm{ad})$,

$\mathrm{h} v \rightarrow \mathrm{e}^{-}+\mathrm{h}^{+}$,

$\mathrm{O}_{2}^{-}(\mathrm{ad})+\mathrm{h}^{+}=\mathrm{O}_{2}(\mathrm{~g})$.

An alternative way for surface modification can be attained by coating NPs with surface modifying reagents which trigger toxicity to bacteria, and can cause differences in $\mathrm{Zn}^{2+}$ ions release and ROS generation [85]. Hsu et al. [86] as well, completed an investigation on how the different surfactant molecules can result in varying antibacterial properties of $\mathrm{ZnO}$-NPs.

\subsection{Influence of $\mathrm{ZnO}$ Particle Size and Concentration}

Particle size and concentration of ZnO-NPs play important roles in the antibacterial activity. ZnO-NPs antibacterial activity directly correlates with their concentration as reported by several studies, likewise, the activity is size dependent, however, this dependency is also influenced by concentration of NPs. Larger surface area and higher concentration are accountable for $\mathrm{ZnO}-\mathrm{NPs}$ antibacterial activity [40, 87]. ZnO-NPs of smaller sizes can easily penetrate into bacterial membranes due to their large interfacial area, thus enhancing their antibacterial efficiency. A large number of studies investigated on the considerable impact of particle size on the antibacterial activity, and the researchers found that controlling ZnO-NPs size was crucial to achieve best bactericidal response, and $\mathrm{ZnO}-\mathrm{NPs}$ with smaller size (higher specific surface areas) showed highest antibacterial activity $[40,51,88]$. The dissolution of $\mathrm{ZnO}-\mathrm{NPs}$ into $\mathrm{Zn}^{2+}$ was reported as size dependent, and few studies suggested this dissolution of $\mathrm{Zn}^{2+}$ responsible for toxicity of ZnO-NPs. The effect of size and concentration was successfully analyzed by a work carried by Padmavathy and Vijayaraghavan [12] who described the 
generation of $\mathrm{H}_{2} \mathrm{O}_{2}$, which depends mainly on the surface area of $\mathrm{ZnO}$. The larger the surface area and the higher concentration of oxygen species on the surface can obtain greater antibacterial activity by smaller particles, which was in contrast to that of Franklin et al. [89] who found no size-related effect. In general, a correspondence between NPs size and bacteria appears to be required for the bioactivity of $\mathrm{ZnO}-\mathrm{NPs}$, as well the concentration. Yamamoto [51] examined the influence of $\mathrm{ZnO}-\mathrm{NPs}$ size $(100-800 \mathrm{~nm})$ on the antibacterial activity, against $S$. aureus and $E$. coli by changing the electrical conductivity with bacterial growth. It was concluded that decrease in particle size will increase the antibacterial activity. Similarly, it was found that ZnO-NPs antibacterial activity toward S. aureus and E. coli increases with decreasing the size $[8,12,40]$. Size-dependent bactericidal activity was also extensively evaluated by Raghupathi et al. [13]. The authors targeted a number of major gram-negative and gram-positive strains, and revealed that ZnO-NPs antibacterial activity was inversely proportional to the particle size. Based on the growth curves and percentage viability, their findings revealed that the activity is size dependent, where smaller sized ZnO-NPs possess best antimicrobial action under visible light. The results illustrated in Fig. 3a-f. Panels a-c show the growth curves obtained from the readings of OD, till $8 \mathrm{~h}$ of incubation, at selected $\mathrm{ZnO}$ concentrations. While panels $\mathrm{d}-\mathrm{f}$ show the inhibition viability, with ZnO-NPs of very small size $(\sim 12 \mathrm{~nm})$, that inhibited about $95 \%$ of the growth with respect to the control $(0 \mathrm{mM})$. Moreover, the effect of different sizes of ZnO-NPs (307, 212, 142, 88, and $30 \mathrm{~nm}$ ) on bacterial growth at $6 \mathrm{mM}$ concentration was studied. By analyzing growth curves at $\mathrm{OD}_{600 \mathrm{~nm}}$, we could perform colony count, and obtain the growth inhibition percentage which was plotted against particle sizes (Fig. 3g). The number of viable cells recovered, at a certain point of growth, showed significant decrease with decreasing $\mathrm{ZnO}$ NPs particle size (Fig. 3h). This was attributed to the increased reactivity of small size NPs, as the generated amount of $\mathrm{H}_{2} \mathrm{O}_{2}$ is significantly dependent on the surface area of $\mathrm{ZnO}-\mathrm{NPs}$ [12]. On the other hand, the antibacterial activity depends on the concentration and the crystalline structure of $\mathrm{ZnO}$. Increased cell death achieved by increasing $\mathrm{ZnO}$ concentrations, which disrupt mitochondrial function, stimulating lactate dehydrogenase leakage and changing the morphology of the cell at concentrations of 50-100 $\mathrm{mg} \mathrm{L}^{-1}$ [90]. Yamamoto [51] found that the higher concentration and the larger surface area can obtain the better antibacterial activity. Also, Jones et al. [8] fulfilled their antibacterial tests using four types of $\mathrm{NPs}\left(\mathrm{TiO}_{2}\right.$, $\mathrm{MgO}, \mathrm{CuO}$, and $\mathrm{CeO}_{2}$ ) which have not considerably inhibited the bacteria growth (more than $10 \mathrm{mM}$ ). These results contradicted those obtained for $\mathrm{ZnO}$ and $\mathrm{Al}_{2} \mathrm{O}_{3} \mathrm{NPs}$, which exhibited significant growth inhibition. The researchers found that just $2 \mathrm{mM}$ of $\mathrm{ZnO}-\mathrm{NPs}$ with reduced sizes decreased bacterial growth by $99 \%$. This result confirmed that the antibacterial activity also depended on the size, and it was probably due to the internalization and subsequent accumulation of NPs inside the cells until the particles reached the cytoplasmic region. In addition, the authors performed the tests in dark, and observed that the antimicrobial effect was weaker. Thus, they concluded that only an ambient laboratory environment could achieve the optimum bactericidal effects, and the reduced size and concentration enhanced this effect. The different conditions, including the type of culture medium and the bacterial cells number, contribute to the variations in antibacterial activity results. Overall, this flourishing study confirms that $\mathrm{ZnO}-\mathrm{NPs}$ are successful candidates for further antibacterial applications owing to their extensive growth inhibition, as a result of the low concentration and smaller particle size. A related study on five oral bacteria showed that $\mathrm{ZnO}$ has bacteriostatic effects on two bacterial strains: Lactobacillus salivarius and Streptococcus sobrinus. However, few inhibitions were observed on the three other types (P. aeruginosa, Streptococcus mutans, and $S$. aureus) according to those tests conditions [90]. This was referred to the size of $\mathrm{ZnO}(100-300 \mathrm{~nm})$ which was larger $(50-70 \mathrm{~nm})$ than that used by Jones et al. In a similar manner, Zhang et al. [62] performed an interesting study using $\mathrm{ZnO}$ nanofluids. Their results showed bacteriostatic action towards E. coli, which increased at higher ZnO-NPs concentrations and reduced size. Furthermore, the authors used SEM analyses to examine the morphological changes. The data showed that ZnO-NPs interacted with E. coli membrane wall resulting in considerable wall damages, which in turn collapsed the cell membrane. Similarly, increasing the concentration of the $\mathrm{ZnO}$ dispersions to $10 \mathrm{mM}$ with extended exposure time (30 min) has inhibited totally E. coli growth [36]. A parallel study was made by Jalal et al. [9] who obtained strong antibacterial activity against $E$. coli at increased concentration. As a result, an increase in $\mathrm{H}_{2} \mathrm{O}_{2}$ amount was produced from $\mathrm{ZnO}$ surface, a lethal species to bacteria.

Also concentration-dependent bactericidal activity of ZnO-NPs was fruitfully evaluated by Xie et al. [91] toward four foodborne pathogens $(C$. jejuni is known as the most common foodborne pathogen, Salmonella enterica Enteritidis, E. coli $\mathrm{O} 157: \mathrm{H} 7$, and Salmonella strains). The researchers treated these strains with $30 \mathrm{~nm} \mathrm{ZnO}-\mathrm{NPs}$ at low concentrations, which indicated complete inhibition of $100 \%$ bactericidal (not bacteriostatic). The $\mathrm{ZnO}$ concentrations were $0,0.025,0.03,0.04,0.05$, and $0.10 \mathrm{mg} \mathrm{mL}^{-1}$. C. jejuni cells were killed at $108 \mathrm{CFU} \mathrm{mL}^{-1}$ after only $3 \mathrm{~h}$, at selected concentrations of $0.1,0.3$, and $0.5 \mathrm{mg} \mathrm{mL}^{-1}$. This result confirms the potent antibacterial effect of $\mathrm{ZnO}$ - 
(a)

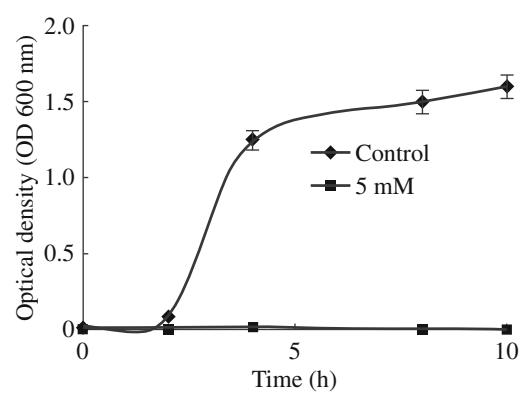

(b)

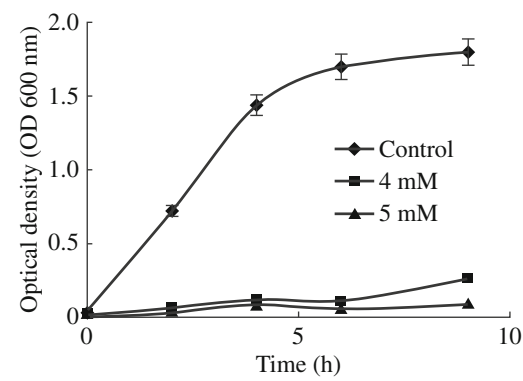

(c)

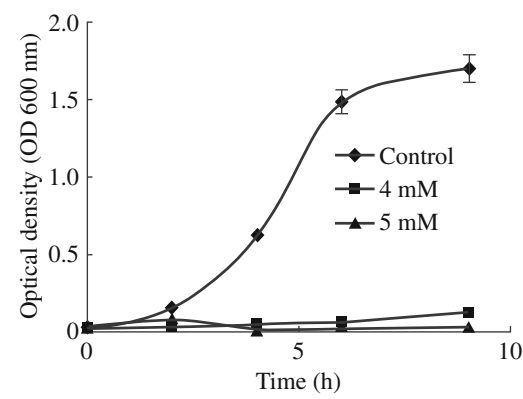

(g)

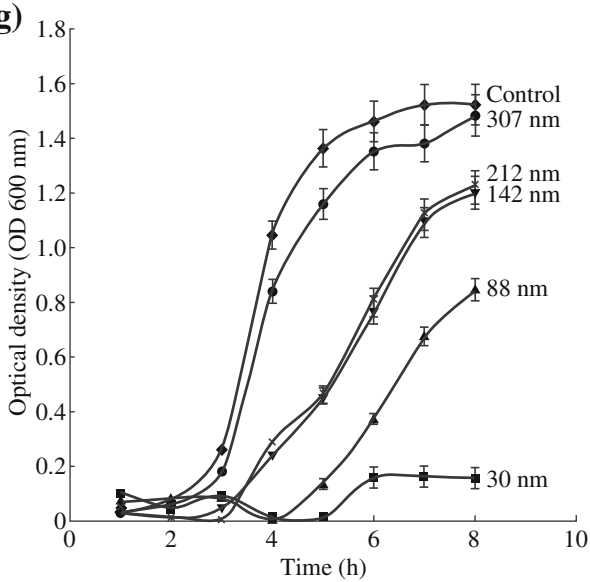

(d)

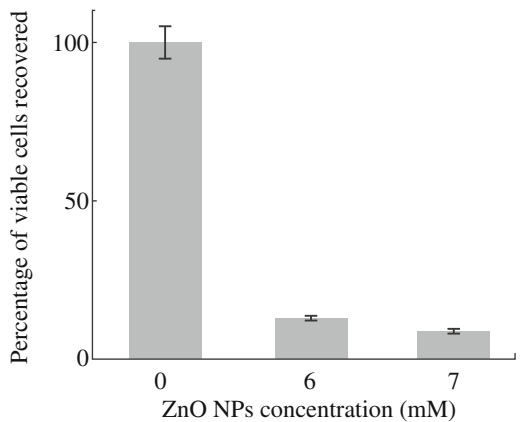

(e)

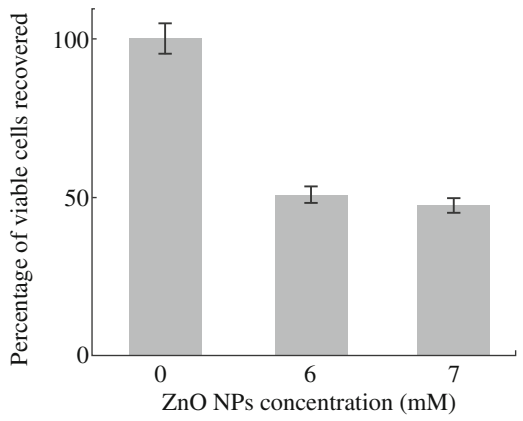

(f)

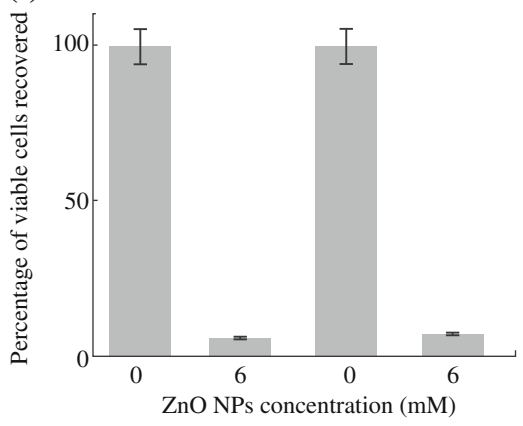

(h)

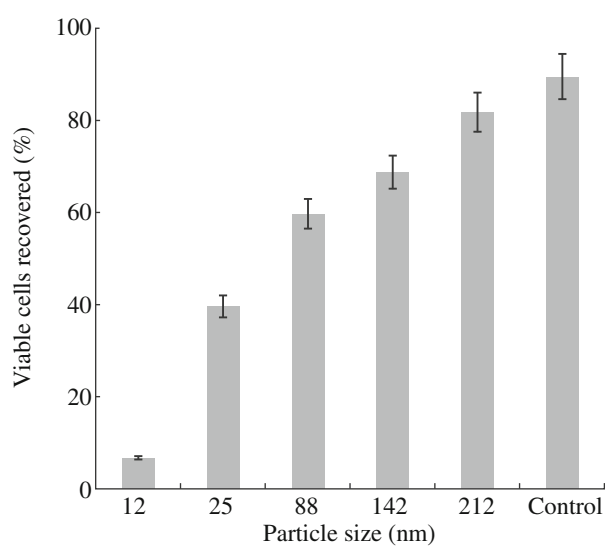

Fig. 3 a-f Growth analysis curves and cells viability percentage, at selected $\mathrm{ZnO}$ concentrations. g Growth curves through optical density $\left(\mathrm{OD}_{600 \mathrm{~nm}}\right)$ measurements. h Percentage of viable cells after overnight incubation. Adapted with permissions from Raghupathi et al. [13] 

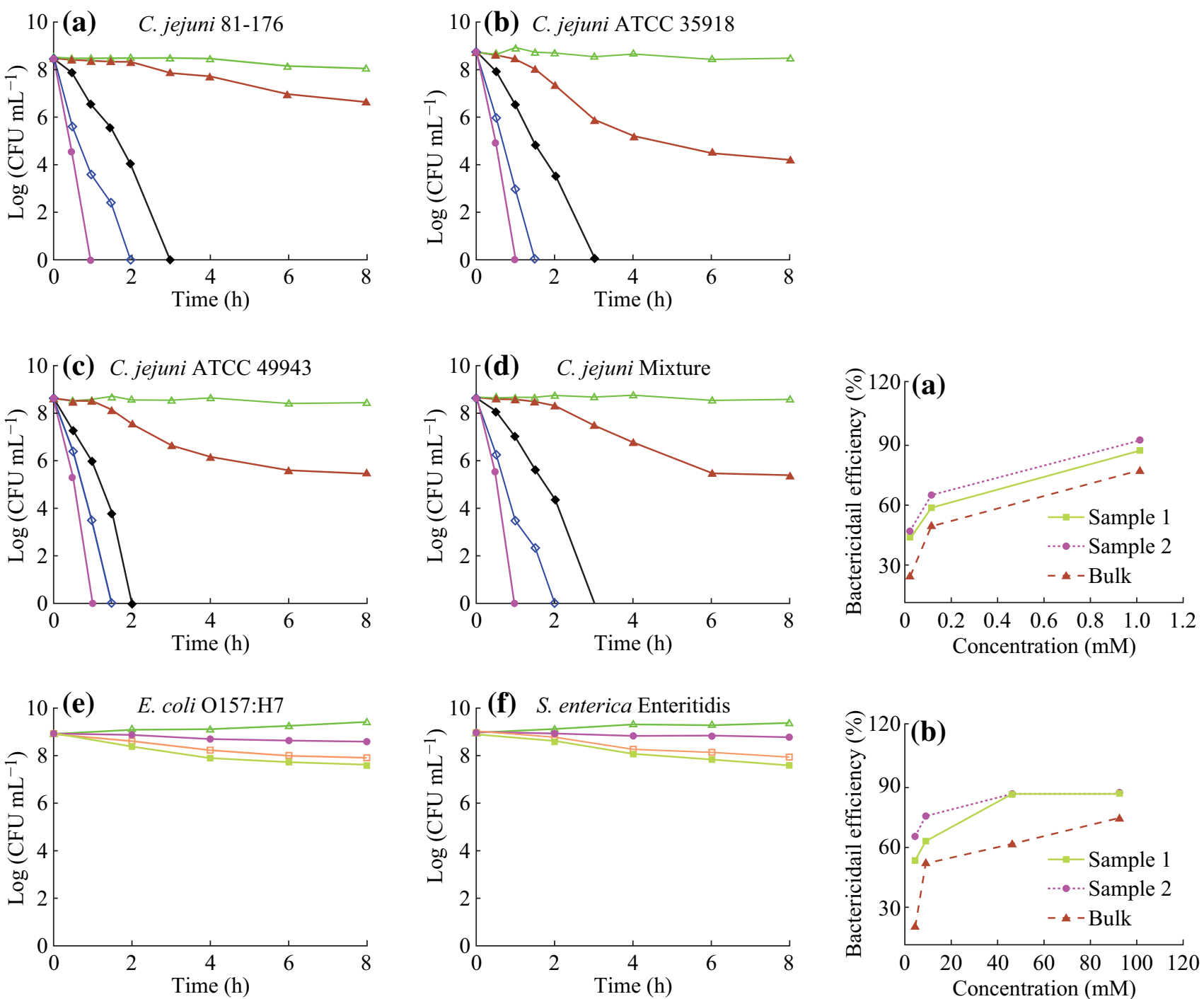

$\rightarrow 0 \mathrm{mg} \mathrm{mL}{ }^{-1} \rightarrow 0.05 \mathrm{mg} \mathrm{mL}^{-1} \rightarrow 0.1 \mathrm{mg} \mathrm{mL}^{-1} \nrightarrow 0.3 \mathrm{mg} \mathrm{mL}^{-1} \rightarrow 0.5 \mathrm{mg} \mathrm{mL}^{-1}$

$\because 5 \mathrm{mg} \mathrm{mL}^{-1}-10 \mathrm{mg} \mathrm{mL}^{-1}$

(A)

(B)

Fig. 4 A Bactericidal efficacies of $\mathrm{ZnO}$ suspensions, for tested samples namely sample 1, sample 2, and bulk with three different particle sizes after $24 \mathrm{~h}$ incubation. Reproduced by permission from Padmavathy and Vijayaraghavan [12]. B Antibacterial activity of ZnO-NPs towards: Enteritidis and E. coli $\mathrm{O} 157: \mathrm{H} 7$, adapted from Xie et al. [91]

NPs toward this particular bacterial species at much reduced concentrations, and this finding is highly beneficial in food packaging. Also, they revealed that three strains of this bacterium possess greater degree of susceptibility toward $\mathrm{ZnO}-\mathrm{NPs}$, as determined from the MIC (Fig. 4A: ad), and considered a lethal effect. By contrast, $S$. enterica serovar Enteritidis and E. coli $\mathrm{O} 157: \mathrm{H} 7$ showed a reduction in viable cells number after $8 \mathrm{~h}$ exposure, and the growth inhibition was determined by counting the numbers of CFUs for the bacteria (Fig. 4A: e, f). In case of E. coli O157:H7 (a major foodborne pathogen) showed $100 \%$ growth inhibition in the presence of a $\mathrm{ZnO}$ concentration which is approximately 8-32 times that used for C. jejuni. The efficiency of ZnO-NPs against Salmonella was also tested at lower concentration. $\mathrm{ZnO}-\mathrm{NPs}$ concentrations that are 20-100 times were required for decreasing 1-2 logs of cells viability. The result showed that $\mathrm{ZnO}$ damaged the membrane integrity. Moreover, the antibacterial activity toward S. enterica serovar Enteritidis was also determined at lower concentration. Recently, Palanikumar et al. [92] reported that $\mathrm{ZnO}$-NPs inhibit the growth of Staphylococcus epidermidis in a size- and concentration-dependent 
Table 2 Selected studies show concentration-dependent antibacterial activity of ZnO-NPs

\begin{tabular}{|c|c|c|c|}
\hline Studied concentration & Tested organism & $\mathrm{ZnO}$ synthesis & References \\
\hline $0-10 \mathrm{mM}$ & S. aureus and E. coli & Hydrolysis-zinc acetate & Reddy et al. [50] \\
\hline $0.125,0.25,0.5 \mathrm{~g} \mathrm{dm}^{-3}$ & E. coli & $\begin{array}{l}\text { Microwave-zinc acetate } \\
\text { decomposition }\end{array}$ & Jalal et al. [9] \\
\hline $\begin{array}{l}0.1,0.3 \text {, and } \\
0.5 \mathrm{mg} \mathrm{mL}^{-1}\end{array}$ & $\begin{array}{l}\text { C. jejuni, E. coli } \mathrm{O} 157: \mathrm{H} 7, \text { S. enterica serovar } \\
\text { Enteritidis } \\
\text { Salmonella }\end{array}$ & Suspensions in $\mathrm{ddH}_{2} \mathrm{O}$ & Xie et al. [91] \\
\hline $20,50,100 \mu \mathrm{L}$ & Pseudomonas aeruginosa and $E$. coli & Wet chemical method & $\begin{array}{l}\text { Chitra and Annadurai } \\
\text { [139] }\end{array}$ \\
\hline
\end{tabular}

manner. Their findings revealed as well wide spectrum of antimicrobial activities of $\mathrm{ZnO}-\mathrm{NPs}$ against various microorganisms (Table 2).

\subsection{Minimum Inhibitory Concentration (MIC)}

For discussing MIC and MBC measurements, a comparison between a study reported by Emami-Karvani and Chehrazi [11] and Reddy et al. study [50] was presented. Briefly, an agar diffusion test was performed by inoculating the targeted bacteria (E. coli and $S$. aureus) on NA using $\mathrm{ZnO}-$ NPs at a defined concentration range. The CFU for each plate was then counted and incubated for $24 \mathrm{~h}$ to determine the bacteria growth rates. Autoclaved distilled water $(0.1 \mathrm{~mL})$ was added to the plates that did not show any bacterial growth. The culture was then transferred to a fresh medium without $\mathrm{ZnO}$-NPs. MBC is determined as the lowest concentration that showed no bacteria growth in the fresh medium, whereas MIC is the lowest NP concentration at which colonies are observed on the surface of the fresh medium. In other words, MIC is the concentration which impedes and absolutely prevents bacterial growth. It was found to be 1.5 and $3.1 \mathrm{mg} \mathrm{mL}^{-1}$ for $S$. aureus and E. coli, respectively. These results were consistent with those obtained by Reddy et al., which was $1 \mathrm{mg} \mathrm{mL}^{-1}$ for $S$. aureus and $3.4 \mathrm{mg} \mathrm{mL}^{-1}$ for E. coli. In both data sets, it is clear that the growth inhibition for the gram-negative bacteria clearly occurred at higher $\mathrm{ZnO}$ concentrations. This finding confirms that gram-positive bacteria are more susceptible to inhibition compared to gram-negative bacteria. The inhibition accounts for variations in cell physiology, cell wall constitution, and the metabolism [93, 94]. Additionally, Xie et al. [91] reported that the MIC of ZnO-NPs (30 nm) toward C. jejuni $\left(0.05-0.25 \mathrm{mg} \mathrm{mL}^{-1}\right)$ was 8-16-fold lesser than E. coli $\mathrm{O} 157: \mathrm{H} 7$ and S. enterica serovar Enteritidis $\left(0.4 \mathrm{mg} \mathrm{mL}^{-1}\right)$. It is also obvious that $\mathrm{ZnO}-\mathrm{NPs}$ activity was concentration dependent.

MIC was determined recently in a different approach by Salem et al. [95] against two pathogens enterotoxic E. coli and Vibrio cholerae, causative agents of diarrheal diseases leading to death. The researchers introduced growth curve test besides INT reduction assay in 96-well plates supplemented with bacterial culture and $\mathrm{ZnO}-\mathrm{NPs}$ and Ag-NPs. The OD $(600 \mathrm{~nm})$ was measured after $16 \mathrm{~h}$ incubation at $37{ }^{\circ} \mathrm{C}$. MIC was determined by the lowest concentration of each NPs, which inhibited the growth. Bacterial growth was defined by an at least 2-fold increase of the $\mathrm{OD}_{600 \mathrm{~nm}}$ with respect to the negative control (growth medium only). Additionally, INT assay (a tetrazolium reduction assay) was performed using $P$-iodonitrotetrazolium violet INT to determine lack of metabolic activity and reveal the growth inhibition. INT was added to the cultures in 96-plates and incubated 30 min until a color change occurred. MIC was defined as the lowest NPs concentration which did not show any color change. A higher efficacy was exhibited by $\mathrm{ZnO}-\mathrm{NPs}$ compared to Ag-NPs. ZnO-NPs concentration of $1.6 \times 10^{5}-1.2 \times 10^{6} \mathrm{~mL}^{-1}$ was necessary for killing both pathogens, while Ag-NPs concentration of $5 \times 10^{6}$ $1.2 \times 10^{7} \mathrm{~mL}^{-1}$ was needed to kill the pathogens.

\subsection{Surface Defects}

Other factors that play vital roles on the mechanism are surface defects and surface charges as the surfaces of $\mathrm{ZnO}$ NPs containing numerous edges and corners, and thus have potential reactive surface sites. In spite of its simple chemical formula, $\mathrm{ZnO}$ has very rich defect chemistry [96], which is associated with its antimicrobial activity. Surface defects strongly affect the toxicity of $\mathrm{ZnO}$. For instance, Padmavathy and Vijayaraghavan [12] suggested that the antibacterial action of $\mathrm{ZnO}-\mathrm{NPs}$ is due to the membrane injury caused by defects such as edges and corners, which results from the abrasive surface of $\mathrm{ZnO}$. Interesting applications of $\mathrm{ZnO}$-NPs can be achieved by controlling the defects, impurities, and the associated charge carriers. Defects extensively change grain boundary properties and the IV characteristics [23].

Finally, Wang et al. [97] proposed the orientation of $\mathrm{ZnO}$ which affects the biocidal activity of $\mathrm{ZnO}$ because of its various randomly oriented spatial configurations, which exhibits higher antibacterial action compared with those of regularly arranged structures [12, 80]. As well, Ramani 
et al. [79] referred the toxicity of nanostructured $\mathrm{ZnO}$ to their orientation, while, it has been found as irrelevant for crystallographic orientation [98]. The inconsistency made the effect under research.

Besides $\mathrm{ZnO}$, other NPs including $\mathrm{Ag}, \mathrm{MgO}, \mathrm{TiO}_{2}$, $\mathrm{CuO}, \mathrm{CaO}, \mathrm{CeO}_{2}, \mathrm{SiO}_{2}, \mathrm{Al}_{2} \mathrm{O}_{3}$, and $\mathrm{Fe}_{3} \mathrm{O}_{4}$, exhibit antimicrobial properties and are safe to humans and animals [99]. Metal NPs are known for their extremely ionic characteristics and are synthesized with different morphologies that exhibit remarkable crystallinity and highly surface area. The surfaces of these NPs are reactive due to plentiful corners and edges [100]. However, some metal oxides are highly toxic, for example, $\mathrm{Al}_{2} \mathrm{O}_{3}$ toxicity toward many cells [8]. Moreover, Ag-NPs toxicity was reported [3, $101,102]$ and $\mathrm{TiO}_{2}$ was revealed to kill a number of bacteria [8, 103, 104]. Adding such metals to $\mathrm{ZnO}$ as precursor could lead to remarkable results, and the precipitation method reported by Zhang [68] who reported that silverloaded $\mathrm{ZnO}$ showed extreme increase of $\mathrm{ZnO}$ antibacterial activity. Ag-loaded $\mathrm{ZnO}$ speculated as a new kind of precursor for inorganic antibacterial agents.

\section{Proposed Mechanisms of Antibacterial Activity}

\subsection{Reactive Oxygen Species (ROS) Generation}

The toxicity of ROS to bacteria is attributed to their high reactivity and oxidizing property [105], it has been reported that aquatic $\mathrm{ZnO}-\mathrm{NPs}$ suspensions produce augmented level of ROS. Numerous studies have considered ROS generation as the major cause of nanotoxicity $[7,56,105-$ 107]. The photocatalytic generation of ROS has been a major contributor to the antibacterial activities of various metal oxides [108]. Several studies indicated ROS formation as the main mechanism responsible for ZnO-NPs antibacterial activity [9, 12, 51, 60, 62]. Raghupathi et al. [13] showed that enhanced $\mathrm{ZnO}$ antibacterial activity was due to the increased ROS production from $\mathrm{ZnO}$ under UV exposure. Such reactive species are superoxide anion $\left(\mathrm{O}^{2}\right)$, hydrogen peroxide $\left(\mathrm{H}_{2} \mathrm{O}_{2}\right)$, and hydroxide $\left(\mathrm{OH}^{-}\right)$. The toxicity of these species involves the destruction of cellular components such as lipids, DNA, and proteins, as a result of their internalization into the bacteria cell membrane. However, the role of ROS in the antimicrobial actions has become an argument issue among the researchers in this field [13]. The creation of ROS seems to be contradictory since a number of studies have revealed this mechanism under light exposure, as mentioned earlier. While alternative studies reported the activity even in the dark [56, 74]. The creation of ROS in the dark was observed by Hirota et al. [74] by testing ZnO-NPs toward E. coli. They found that the activity can occur under darkness, producing superoxide species; which is in consistence with Jones et al. findings [8]. Such consistent results give a sign of possibly further mechanisms so far to be determined to produce reactive species without illumination and in dark. Therefore, further studies are required to explain these findings deeply. An important clarification studied by Padmavathy and Vijayaraghavan [12], who used ZnO-NPs of three different sizes $(45,12 \mathrm{~nm}$, and $2 \mu \mathrm{m}$, namely sample 1, sample 2, and bulk) to determine $\mathrm{ZnO}$ bactericidal efficiency (Fig. 4B). They found that the smaller sized, $12 \mathrm{~nm}$ showed best efficiency compared to $45 \mathrm{~nm}$ and $2 \mu \mathrm{m}$. This was attributed to ROS release on $\mathrm{ZnO}-\mathrm{NPs}$ surface under both UV and visible light, and the ROS release caused lethal bacterial injury. The researchers explained the production of $\mathrm{ROS}\left(\mathrm{OH}^{-}, \mathrm{H}_{2} \mathrm{O}_{2}\right.$, and $\left.\mathrm{O}_{2}^{2-}\right)$ on $\mathrm{ZnO}$ surface and proposed a correlation between photon reactions and the antibacterial activity as follows.

The electron and hole interacts with water $\left(\mathrm{H}_{2} \mathrm{O}\right)$ to produce ${ }^{\bullet} \mathrm{OH}$ and $\mathrm{H}^{+}$. In addition, $\mathrm{O}_{2}$ molecules (suspended within the mixture of bacteria and $\mathrm{ZnO}$ ) yield superoxide anion $\left({ }^{\bullet} \mathrm{O}_{2}^{-}\right)$, which reacts with $\mathrm{H}^{+}$to produce $\mathrm{HO}_{2}^{\bullet}$. Afterward, $\mathrm{HO}_{2}^{\bullet}$ interferes with electrons generating hydrogen peroxide $\left({ }^{\bullet} \mathrm{HO}_{2}\right)$; which combines with $\mathrm{H}^{+}$giving hydrogen peroxide $\left(\mathrm{H}_{2} \mathrm{O}_{2}\right)$ molecules. The latter are capable to enter the membrane where they either damage or kill the bacteria. $\mathrm{H}_{2} \mathrm{O}_{2}$ generation mainly relies on the surface of $\mathrm{ZnO}-\mathrm{NPs}$ to yield additional active molecules. There is a linear proportionality between the concentrations of $\mathrm{H}_{2} \mathrm{O}_{2}$ produced in $\mathrm{ZnO}$ slurry and the $\mathrm{ZnO}$ particle size [88]. The mentioned researchers expressed the generated ROS by chemical equations as follows:

$$
\begin{aligned}
& \mathrm{ZnO}+\mathrm{hv} \rightarrow \mathrm{e}^{-}+\mathrm{h}^{+}, \\
& \mathrm{h}^{+}+\mathrm{H}_{2} \mathrm{O} \rightarrow{ }^{\bullet} \mathrm{OH}+\mathrm{H}^{+}, \\
& \mathrm{e}^{-}+\mathrm{O}_{2} \rightarrow{ }^{\bullet} \mathrm{O}_{2}^{-}, \\
& { }^{\bullet} \mathrm{O}_{2}+\mathrm{H}^{+} \rightarrow \mathrm{HO}_{2}^{\bullet}, \\
& \mathrm{HO}_{2}^{\bullet}+\mathrm{H}^{+}+\mathrm{e}^{-} \rightarrow \mathrm{H}_{2} \mathrm{O}_{2} .
\end{aligned}
$$

The superoxides and hydroxyl radicals cannot penetrate into the membrane due to their negative charges [91]. Thus, these species are found on the outer surface of the bacteria, by contrast, $\mathrm{H}_{2} \mathrm{O}_{2}$ molecules are able to pass through the bacterial cell wall, subsequently leading to injuries and destroy, and finally triggering cell death [40, 88]. When $\mathrm{ZnO}-\mathrm{NP}$ kills or interacts with the cell membrane, the particles most probably stay firmly adsorbed at the surface of the left over/killed bacteria blocking additional antibacterial activity. Once $\mathrm{ZnO}-\mathrm{NPs}$ are in the growth media, they will carry on releasing peroxides covering the entire surfaces of the dead bacteria. Therefore, this continuous peroxide release leads to higher bactericidal efficacy. 
The production of ROS has been concerned in the onset and development of many diseases (such as cancer, atherosclerosis, diabetes, and neurodegeneration). In this regard, investigation of sensitive ROS detection probes has been of utmost importance and was carried by some researcher. A fluorescent dye dichlorodihydrofluorescein diacetate (DCFH-DA) has been used recently to detect the intracellular ROS levels in bacteria and cancer cell lines $[109,110]$. Thus, the mechanism related to the formation of ROS in bacteria and cell line was clearly examined by the measurement of ROS level using DCFH-DA [111]. Production of ROS by metal NPs in cell lines has been revealed by several studies [111-113], and referred to the inhibition of the respiratory enzymes [114]. Previously, it was documented that ROS production in bacteria was mostly due to the autoxidation of NADH dehydrogenase II in the respiratory system [115].

The mechanism of antibacterial activity by ROS generation due to treatment with ZnO-NPs using DCFH-DA dye was studied by Dwivedi et al. [109]. The dye passively enters into the bacterial cell, and then is hydrolyzed by cell esterases to DCFH which is oxidized to DCF, a highly fluorescent compound dichlorofluorescein in the presence of ROS. The fluorescence was determined by flow cytometry or microplate reader, the fluorescent intensity is proportional to the amount of ROS [116].

$\mathrm{DCFH}-\mathrm{DA} \longrightarrow[$ esterases $] \mathrm{DCFH} \rightarrow \mathrm{DCF}$.

\subsection{Zinc Ions $\left(\mathrm{Zn}^{2+}\right)$ Release}

One of the main proposed antibacterial mechanisms for $\mathrm{ZnO}-\mathrm{NPs}$ is release of zinc ions in medium containing ZnO-NPs and bacteria [47, 59, 110, 117, 118]. The released $\mathrm{Zn}^{2+}$ has significant effect in the active transport inhibition as well as in the amino acid metabolism and enzyme system disruption. Several studies have believed that the leaked $\mathrm{Zn}^{2+}$ into growth media responsible for $\mathrm{ZnO}$ nanotoxicity and the dissolution of $\mathrm{ZnO}-\mathrm{NPs}$ into $\mathrm{Zn}^{2+}$ were found as size dependent. Therefore, engineered nanostructures might modify their toxicity by manipulating the dissolution rate $[80,107,117,119,120]$. Kasemets et al. [57] have shown that the release of $\mathrm{Zn}^{2+}$ ions was a logical cause of $\mathrm{ZnO}$ toxicity toward Saccharomyces cerevisiae bacteria (these bacteria is highly considered in food processing). According to this hypothesis, $\mathrm{ZnO}$-NPs toxicity is referred to the solubility of $\mathrm{Zn}^{2+}$ in the medium including the bacteria. Therefore, solubilized low concentrations $\mathrm{Zn}^{2+}$ can induce a comparatively high tolerance in bacteria. Reddy et al. [50] treated E. coli with a low concentration $(1 \mathrm{mM})$ of solubilized $\mathrm{Zn}^{2+}$. On contrast, Sawai [48] and Jiang et al. [121] described the contribution of $\mathrm{Zn}^{2+}$ to the antimicrobial efficacy of $\mathrm{ZnO}-\mathrm{NPs}$ as minor due to the low concentrations of solubilized $\mathrm{Zn}$ species released from $\mathrm{ZnO}$ dissolution. The aforementioned studies reported the mechanism as predominant. So the dissolution phenomenon is somewhat under debate, although it has been adopted and accepted. Additionally, $\mathrm{Zn}^{2+}$ release would be limited by an inherent $\mathrm{ZnO}$ property, mentioned earlier $\mathrm{ZnO}$ stability in water. The insolubility of $\mathrm{ZnO}$ impedes the distribution of zinc ions into the medium and thus limits this antimicrobial effect [118], unless $\mathrm{ZnO}$ capped or stabilized. The physicochemical properties of $\mathrm{ZnO}-\mathrm{NPs}$ and dissolved zinc species depend upon the medium components. Though, Pasquet et al. [122] summarized that $\mathrm{Zn}^{2+}$ release mechanism affected by two main parameters: (i) the physicochemical properties of the particles including porosity, concentration, particle size, and morphology. (ii) The chemistry of the media: the $\mathrm{pH}, \mathrm{UV}$ illumination, exposure time, and existence of other elements. However, the influence of these parameters is not entirely elucidated. Peng et al. [87] observed the morphology-dependent release of $\mathrm{Zn}^{2+}$ ions on spherical structures that had the highest increase in the release of $\mathrm{Zn}^{2+}$ ions than rod structures. It was elucidated on the fact that smaller surface curvature of sphere causes high equilibrium solubility. Also, Wang et al. [123] studied the morphology-dependent dissolution of metal ions. Leung et al. [85] proposed that the most probable mechanisms can be influenced by surface modifications because both the liberation of $\mathrm{Zn}^{2+}$ ions and ROS creation occur on NPs surface. Moreover, the surface properties affect the reactions on the bacterial cell walls. In this regards, characterizations techniques assist in recognizing the mechanisms such as SEM, XRD, TEM, and ESI. For example, ESI is used to investigate the elemental distribution of $\mathrm{ZnO}$ particle surfaces. In our study [83], where ESI elemental mapping results showed a higher $\mathrm{O}: \mathrm{Zn}$ ratio on the surface of $\mathrm{ZnO}$-rod structure but lower $\mathrm{O}: \mathrm{Zn}$ ratio on $\mathrm{ZnO}$-plates surfaces. Therefore, $\mathrm{ZnO}$-rod tends to have relatively higher $\mathrm{O}: \mathrm{Zn}$ ratio than other $\mathrm{ZnO}$-structures, i.e., higher amounts of oxygen atoms on rod surface, which generates ROS causing intense oxidative stress toward the bacteria. Currently, it was found that $\mathrm{Zn}^{2+}$ of $\mathrm{ZnO}$ is capable to interact with protein and has a potential effect to HSV-1 pathogenesis [109].

\subsection{Different Probable Mechanisms}

Further suggestions for the bactericide achievement are the inhibition of energy metabolism, once NPs have internalized bacteria. ZnO-NPs are bactericidal and thus disrupt membrane causing membrane dysfunction, resulting in their internalization into the bacteria (Fig. 5a). ZnO internalization is controlled by the particle size, surface chemistry, defects, and functionalization. Compared with cells 

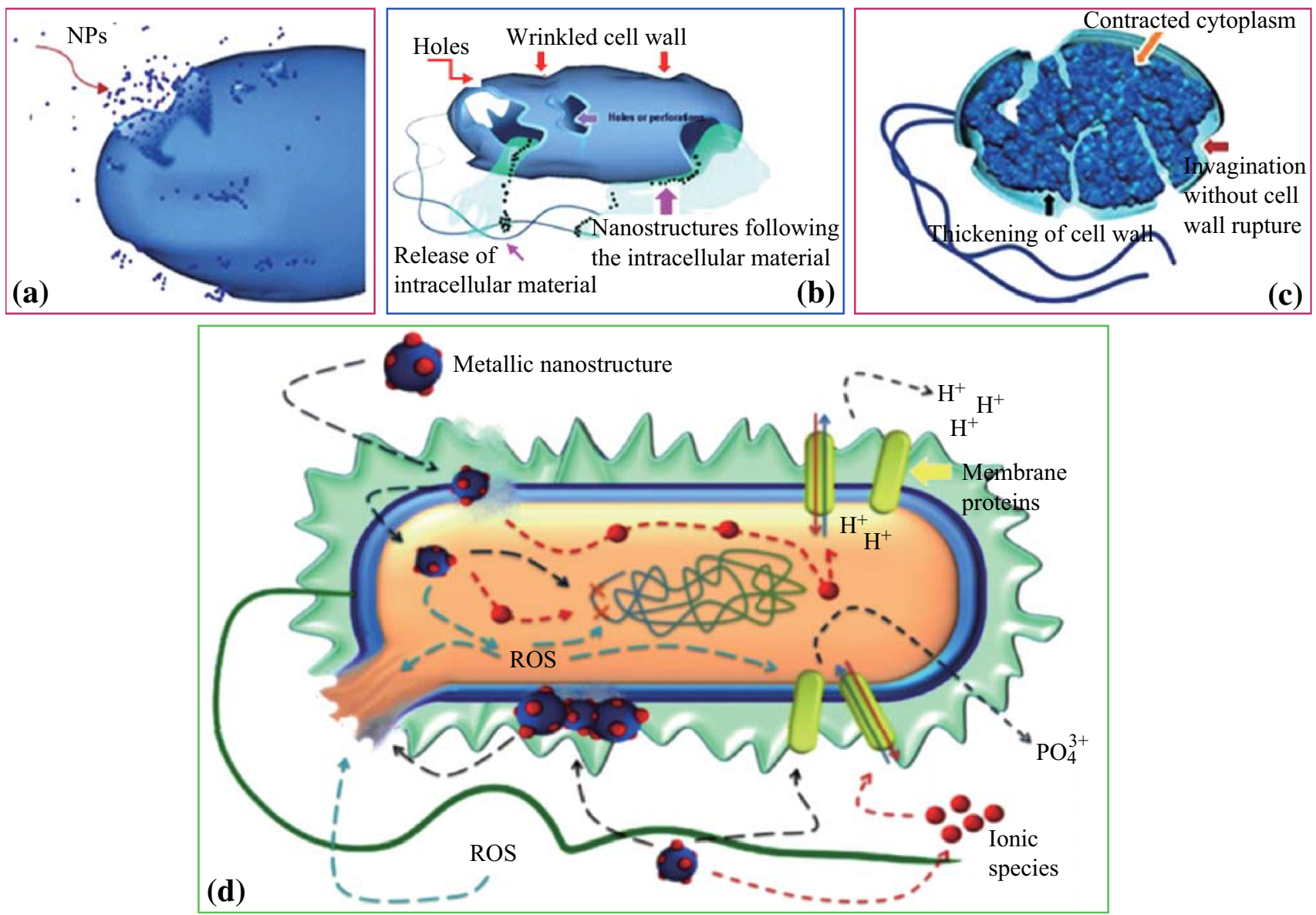

Fig. 5 a NPs internalization into the cell and translocation. NPs penetrate through holes, pits or protrusions in the cell wall. b Schematic representation of collapsed cell showing disruption of cell wall and extrusion of cytoplasmic contents. c Bacterial cell showing important variations in envelope composition (slight invaginations and thickening of cell wall) and extrusion of cytoplasm. d Probable mechanisms, involves the following: metal ions uptake into cells, intracellular depletion, and disruption of DNA replication, releasing metallic ions and ROS generation and accumulation and dissolution of NPs in the bacterial membrane. Reused from Díaz-Visurraga et al. [128]

exposed to Ag-NPs and ions, the cell energy is reduced due to the decline in the adenosine triphosphate levels and the essential energy molecule, and destabilization of the outer membrane was followed [4]. The effect of the $\mathrm{pH}$ value of the reaction medium in the antibacterial activity mechanism has been considered. A value in the neutral region $(\mathrm{pH}$ 7.5) was assumed to have no effect on the antibacterial activity in absence of light [124]. Meanwhile Sawai et al. [60] found that the activity could not be detected for $\mathrm{pH}$ in range of 5.5-8.0. While Stanković et al. [125] varied the $\mathrm{pH}$ value of the starting reaction solution from 8 to 12 that enabled in changing the morphology from micro-rods to nano-spheres, resulting in an efficient bacteriostatic activity.

There is a strong trend that considers two mechanisms underlying the interaction of NPs with bacteria, to be mainly concerned [13]: (i) excessive ROS generation, mostly hydroxyl radicals $\left(\mathrm{HO}^{\bullet}\right)$ and singlet oxygen $\left({ }^{1} \mathrm{O}_{2}\right)$ $[60,80,126,127]$, and (ii) NPs precipitation on the bacterial exterior; or NPs gather in the cytoplasmic area or in the periplasm space, thus, disrupt the cellular activities, resulting in membranes disturbance and disorder [7, 40]. In this way, Zhang et al. [62] referred some of the effect to a direct liaison between NPs and the membrane as well as to ROS generation nearby bacteria membrane. Zhang et al. [62] suggested a creation of electrostatic forces when E. coli treated with $\mathrm{ZnO}$. Stoimenov et al. [100] also proposed this electrostatic interaction between NPs and bacteria cell surface as a cause of growth inhibition, and that the total bacterial charge is negative, because of the excessive formation of separated carboxyl groups. Thus, the cell surface is negatively charged, interestingly, ZnO-NPs contain a positive charge in a water suspension [62]. Such reverse charges enhance the total effect by creating electrostatic forces, which serve as a powerful bond between NPs and bacterial surface. As a result, the cell membrane is damaged. Additionally, Brayner et al. [7] observed that the interaction between $E$. coli and $\mathrm{ZnO}$-NPs yields cell wall 
disorganization followed by internalization of NPs into the cells. They recognized a substantial damage to $E$. coli with disorganized cell walls by SEM images which showed the changed morphology, a consequence of intracellular content leakage. Also, the images showed $\mathrm{ZnO}-\mathrm{NPs}$ both inside and outside the cell bordered probably by lipopolysaccharides released of bacteria. They explained the capability of $\mathrm{ZnO}$-NPs to reduce the bacteria growth. It was attributed to membrane disruption and raises its permeability, which in turn causes the gathering of $\mathrm{ZnO}-\mathrm{NPs}$ inside the membrane and then reaches the cytoplasm. These results are similar to those obtained by Díaz-Visurraga et al. [128] shown in Fig. 5a-c. An identical finding showed the attachment of ZnO-NPs to outer cell wall and passing in the inner wall, causing disruption of the membrane and consequent disorder and leakage [46]. In a similar manner, Xie et al. [91] found that the action of ZnO-NPs on $C$. jejuni has stimulated morphology disorder, intracellular components outflow, and considerable release in gene expression of oxidative stress of $C$. jejuni. In addition to the aforementioned mechanisms, $\mathrm{ZnO}$-NPs have abrasive surface texture which influences the antibacterial mechanism, which in sequence destroys the bacterial membrane [12]. The abrasive property of $\mathrm{ZnO}$ has been recognized and referred to its surface defects [100]. These defects such as corners, edges, and chemistry defects have a major impact on the antibacterial activity in the mechanical damage on cell wall. Surface defects play an important role; Ramani et al. [129] reported that $\mathrm{ZnO}$ nanostructures antibacterial activity is surface-dependent defect which in sequence are shape dependent. Although the detailed mechanism of $\mathrm{ZnO}$ antibacterial activity is under discussion, a three most widely accepted, and reported hypothetical mechanisms in the literature [128] are: (i) metal ions uptake (translocation and particle internalization) into cells followed by depletion of intracellular ATP production and disruption of DNA replication [130], (ii) ROS generation from NPs metal oxides and ions with subsequent oxidative damage to cellular structures [131], and (iii) changes in bacterial membrane permeability (progressive release of lipopolysaccharides, membrane proteins, and intracellular factors) and dissipation of the proton motive force as a result of accumulation and dissolution of NPs in the membrane [132]. These mechanisms were illustrated in Fig. 5a, b, d along with other predicted ones previously mentioned.

\section{A Study of ZnO-NPs Antibacterial Response to $E$. coli}

We present here briefly one study in which we used $\mathrm{ZnO}$ NPs $(80 \mathrm{~nm})$ produced via French process [28] of high purity (>99.97\%). A stock solution was prepared in $\mathrm{ddH}_{2} \mathrm{O}$, and vigorously vortexed $(3 \mathrm{~min})$ and subjected to high ultrasonication $(30 \mathrm{~min})$ prior to addition to culture mixture, and diluted to concentrations 1-4 mM. Two samples were used to treat $E$. coli (ATCC 25922), ZnO-AP (as purchased), and $\mathrm{ZnO}-\mathrm{O}_{2}$ (oxygen annealed). $\mathrm{ZnO}$ powder was annealed at $700{ }^{\circ} \mathrm{C}$ in an annealing tube furnace (model Lenton) under oxygen ambient for $1 \mathrm{~h}$. The gas flow was regulated at $2.4 \mathrm{~L} \mathrm{~min}^{-1}$. Bacteria and $\mathrm{ZnO}$ mixture were prepared in 96-well plate including control and incubating in $5 \%, \mathrm{CO}_{2}, 37^{\circ} \mathrm{C}$ incubator chamber, as described below.

Bacterial culture conditions for the antibacterial tests were conducted. E. coli was freshly prepared, grown in NA broth, and incubated for $24 \mathrm{~h}$ at $37^{\circ} \mathrm{C}$, and then supplemented with four concentrations of $\mathrm{ZnO}-\mathrm{NPs}$ suspensions to study the bacterial growth rate. Then the inoculum preparation and inoculation was carried by preparing standardized inoculums of $E$. coli containing ap-

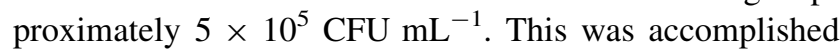
by diluting the $0.5 \mathrm{McFarland}$ suspension 1:150, resulting in a tube containing approximately $1 \times 10^{6} \mathrm{CFU} \mathrm{mL}^{-1}$. Within 15 min after the inoculum has been standardized as described above, a $150 \mu \mathrm{L}$ of the adjusted inoculums was added into the 96-well microplate containing $150 \mu \mathrm{L} \mathrm{ZnO}$ in the dilution series, and triplicated for each concentration. The controls, positive control ( $\mathrm{ZnO}$ and TSB), and negative control (bacteria and TSB) were prepared for each set of experiment. All types of serial concentration of $\mathrm{ZnO}$ were mixed with relevant bacteria. This resulted in a 1:2 dilution of each $\mathrm{ZnO}$ concentration and a 1:2 dilution of the inoculums $5 \times 10^{5} \mathrm{CFU} \mathrm{mL}^{-1}$.

Then the mixture in the 96-well plate were exposed to UVA light $\left(390 \mathrm{~nm}, 1.8 \mathrm{~mW} \mathrm{~cm}^{-2}\right.$ ) for $20 \mathrm{~min}$, and consequently OD measurements were held hourly up to $8 \mathrm{~h}$, and then after $24 \mathrm{~h}$ to determine the percentage growth inhibition. Additionally, cells were fixed to be viewed by FESEM to observe the bacterial morphological changes after treated with ZnO-NPs. Cells were mounted on specimen stub using a double-sided carbon tape and coated with platinum.

The percentage inhibition (after $24 \mathrm{~h}$ incubation) was calculated from the OD readings as follows.

Results were displayed in Fig. 6, it was observed that higher concentration of $\mathrm{ZnO}$ caused higher bacterial inhibition. Moreover, the UV illumination increased the percentage inhibition of bacteria (Fig. 6e, f). As it is known that $\mathrm{ZnO}$ absorbs UV light, it has an excellent photocatalytic property, thus it is believed that UV stimulated the $\mathrm{ZnO}$ in the mixture to release electrons, which leads to produce more oxygen within the mixture. This phenomenon induced the generation of ROS from $\mathrm{ZnO}$ surface, as described earlier. $\mathrm{ZnO}-\mathrm{O}_{2}$ had exhibited the 

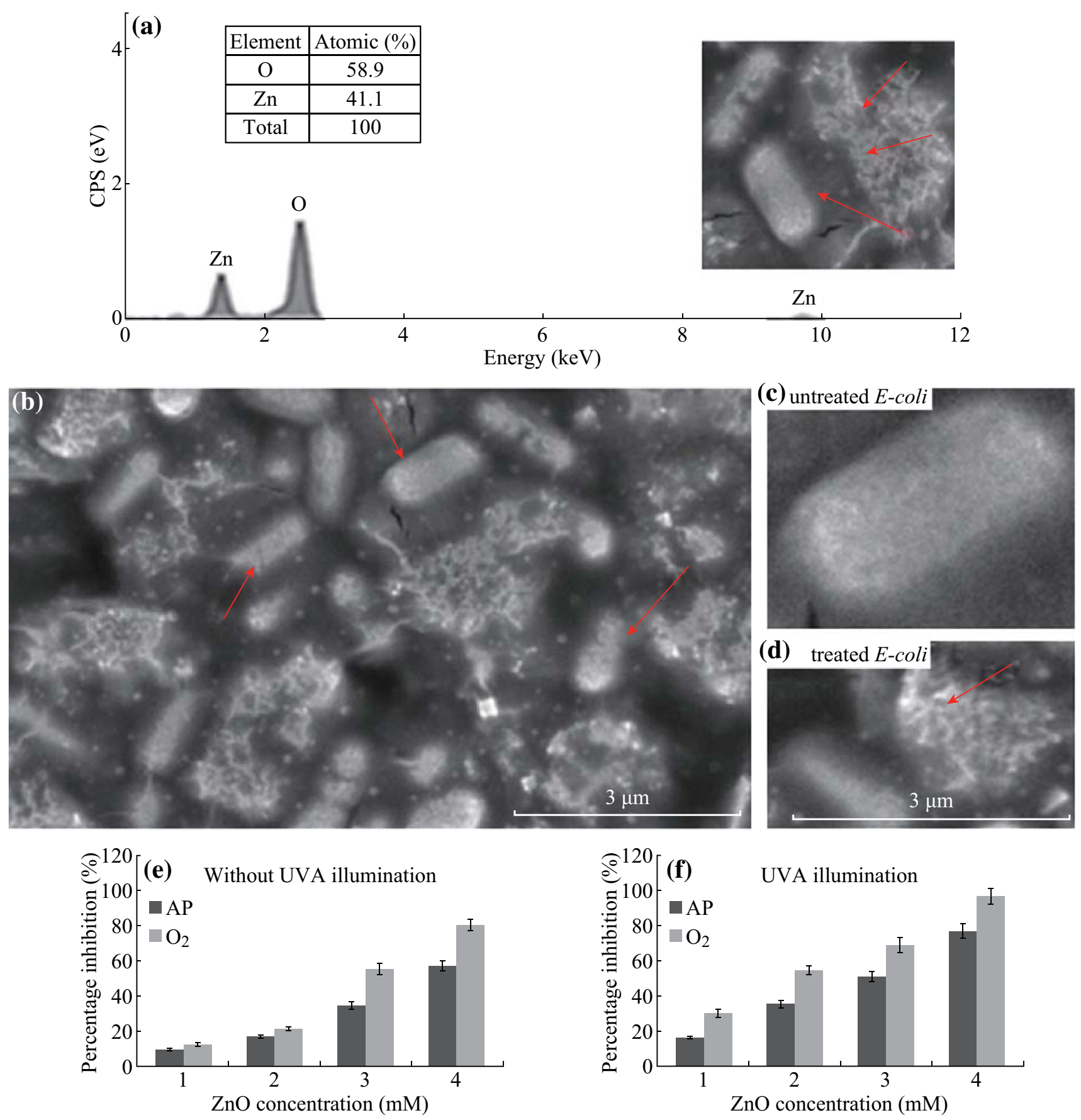

Fig. 6 a EDS spectrum of $E$. coli in $\mathrm{ZnO}$ mixture, b FESEM micrographs of $E$. coli exposed to $\mathrm{ZnO}$, arrows show $\mathrm{ZnO}$ particles on the bacteria surface, $\mathbf{c}$ untreated bacteria cells, $\mathbf{d}$ E. coli treated with $\mathrm{ZnO}$, and $\mathbf{e}, \mathbf{f}$ percentage inhibition of $E$. coli treated with $\mathrm{ZnO}-\mathrm{AP}$ and $\mathrm{ZnO}-\mathrm{O}_{2}$ at different concentrations with and without UVA illumination, respectively (experiment was done by authors of this manuscript, triplicated)

highest growth inhibition capability toward E. coli than $\mathrm{ZnO}-\mathrm{AP}$. This was most likely attributed to the higher surface defects induced by annealing. The oxygen annealing stimulated a high level of oxygen atoms to be absorbed onto the surface of $\mathrm{ZnO}$, which was revealed by the EDS spectrum (Fig. 6a). Additionally, the release of electrons was believed to interact with the bacteria where the electron discharges the bacteria membrane halting the bacterial growth.

The FESEM images (Fig. 6b-d) show ZnO-NPs on the bacteria surfaces, which probably inhibited the growth due to the generated ROS into the mixture of $\mathrm{ZnO}$ with E. coli, which was enhanced by the UV exposure and also the annealing process causing oxygen absorption on the 
surface of $\mathrm{ZnO}$ samples. The high amount of oxygen on the surface induced ROS release in $\mathrm{ZnO}$ suspension. The images also show that $\mathrm{ZnO}$ did not penetrate into the cell membrane and thus no considered damage was observed on cells structural morphology, but inhibited the growth. This might be probably suggested that the size of the particles did not allow their penetration into the cell wall and membrane. Our results of this experiment were in agreement with some studies [9, 12, 13], which showed that enhanced $\mathrm{ZnO}$ antibacterial response is referred to the increased ROS production under UV light. And also with Zhang et al. [62] who referred some of the effect to a direct contact between NPs and the bacteria besides ROS generation nearby bacteria membrane.

\section{ZnO-NP as an Antibacterial Agent in Food}

Research on $\mathrm{ZnO}-\mathrm{NPs}$ as antibacterial agent has become interdisciplinary linking physicists, biologists, chemists, and medicine, hence it is the wide spread of their applications. One of these essential applications is in food industry; as an antibacterial agent in food packaging and towards foodborne pathogen. Nanomaterials possess great concern in food technology for their high reactivity, enhanced bioavailability and bioactivity, and have creative surface possessions [133]. Some of the main benefits of using NPs in food nanotechnology are the addition of NPs onto food surfaces to inhibit bacterial growth, also using of NPs as intelligent packaging materials and for nano-sensing [134]. Among these NPs, ZnO-NPs developed as a successful candidate in the food industry $[71,135]$. The antibacterial influence of $\mathrm{ZnO}-\mathrm{NPs}$ against foodborne pathogens stimulates proficient applications in food packaging, and can be introduced in food nanotechnology. Duncan [136] reported about recent applications of antimicrobial NPs on food, to achieve high barrier packaging materials, and nano-sensors using NPs to trace food-relevant analytes such as foodborne pathogens. Generally, food industry witnessed revolution by the implementation of nanotechnology.

\subsection{Food Pathogens}

Recently, the need for novel technologies to control foodborne pathogens is increasing, due to the alarming increase in fatalities and hospitalization worldwide. Foodborne illnesses are an increasing major health problem in both developing and developed countries. Each year, 1 million people in the UK acquire foodborne illness, 20,000 people undergo hospitalization, and 500 deaths. As announced by the Food Standards Agency, which is a program for the reduction of food-borne diseases in the UK. The spread of foodborne diseases can result in many social problems such as poverty, health problems, and even economic issues. Moreover, in recent years, the pathogenic bacteria have exhibited antimicrobial resistance, and this emerged as hot subject of discussion among researchers in this field. Some most common bacterial foodborne pathogens are $C$. jejuni, C. perfringens (is the cafeteria germ), Salmonella spp., and E. coli O157:H7. Several studies were conducted to determine the interaction of $\mathrm{ZnO}-\mathrm{NPs}$ with foodborne pathogens, since $\mathrm{ZnO}-\mathrm{NPs}$ are listed as being safe (US FDA). Studies showed that ZnO-NPs can inhibit and kill common as well as major foodborne pathogens. The bactericidal activity of ZnO-NPs (8-10 nm size) against E. coli DH5 $\alpha$ and $S$. aureus was examined and found to be effective at 80 and $100 \mu \mathrm{g} \mathrm{mL}^{-1}$. These concentrations disrupted the cell membrane causing cytoplasmic leakage [137]. Narayanan et al. [138] tested the antibacterial activity of ZnO-NPs against some human pathogens such as $P$. aeruginosa, E. coli, S. aureus, and E. faecalis. They emerged with the result that ZnO-NPs have strong antibacterial activity toward these human pathogens. Likewise, the antimicrobial activity of ZnO-NPs was studied [139] toward $P$. aerugi$n o s a$ and $E$. coli which were isolated from mint leaf extract and frozen ice cream, and $\mathrm{ZnO}$ was prepared using wet chemical method, yielding spherical morphology with smooth surface, of concentrations 20,50, and $100 \mu \mathrm{L}$. Both bacteria showed decreased growth rate at the highest concentration $100 \mu \mathrm{L}$, and they explained the growth inhibition as a result of cell membrane damage through penetration of ZnO-NPs. They concluded that ZnO-NPs synthesized by wet chemical method are potential antibacterial agents in food preservation and packaging.

\subsection{Food Packaging Applications}

Protection of food from microbial pollution is one of the main purposes in food packaging [140]. The emergence of nanotechnology assisted to present novel food packaging materials with antimicrobial properties and with novel nano-sensors to trace and monitor the food [135]. Several studies have addressed the antibacterial properties and potential applications of $\mathrm{ZnO}-\mathrm{NPs}$ in food processing. For example, $\mathrm{ZnO}$ has been included into a number of food linings in packaging to avoid spoilage plus it maintains colors. ZnO-NPs provide antimicrobial activity for food packaging. Once they are introduced in a polymeric matrix, it permits interaction of food with the packaging possessing functional part in the conservation. Other benefits also are achieved such as the barrier properties, constancy, and mechanical capability [71]. The use of polymer nanotechnology in packaging was introduced by Silvestre et al. [135] to achieve novel way of packaging that mainly meet the requirements of protection against bacteria. These new 
materials with improved antimicrobial properties permit also tracking of food during storage and transfer.

\subsubsection{Active Packaging}

Recently, active food packaging systems as an emergent approach in food packaging have replaced the conventional packaging systems to achieve effective performance. The conventional approach uses a passive barrier to protect food against the surrounding atmosphere [141]. While, active packaging create an effective antimicrobial action on food, and saves the inert products from the environmental factors. The liberation of the NPs, which acts as bacteriostatic or bactericidal agents onto the food surface where bacteria reside, halts the growth and thus prevents food from spoilage [141]. This type of active packaging is also called antimicrobial packaging, where direct interaction occurs between the product and the NPs leading to the killing or inhibition of bacterial growth on food surfaces [142]. Accordingly, direct addition of highly concentrated antibacterial to a packed food is not recommended. The inclusion of antibacterial agents assists either bacteriostatic or bactericidal materials to gradually diffuse into the food matrix. Hence, reducing the possibility of pathogen contamination and thus a safe product with an extended shelf life was obtained. Ahvenainen [143] stated that active packaging satisfies the consumer demand as it enhances safety, with more natural products of extended life time. The packaging materials are firstly characterized before incorporating with ZnO-NPs by microscopic and spectroscopic techniques. In XRD, a scattered intensity of X-ray beam on the sample provides information about the studied material such as chemical composition, crystallographic structure, and physical properties. Also, images of the NPs interacted with the packaging materials can be obtained by SEM and TEM. Besides, FTIR is used to reveal the chemical changes after NP incorporation.

\subsubsection{Intelligent Packaging and Smart Packaging}

Intelligent packaging has intelligent functions, such as sensing, detecting, tracing, recording, and communicating [140]. This system utilizes a number of indicators for monitoring the food quality in terms of microbial growth as well as temperature and packing integrity [144, 145], whereas smart packaging possesses the susceptibilities of intelligent and active packaging.

\section{Conclusions and Future Perspective}

This current review aimed to discuss and analyze research works that addressed the potential use of $\mathrm{ZnO}-\mathrm{NPs}$ for antibacterial activity. Extensive discussion was centered on the antibacterial activity of $\mathrm{ZnO}-\mathrm{NPs}$ coupled with a number of influenced factors impacting the activity. Mainly, by improving factors like UV illumination, $\mathrm{ZnO}$ particle size, concentration, morphology, and surface modification, powerful antibacterial results would be obtained. These factors influence a variety of toxicity mechanisms. Special focus was given to mechanisms of action which come as the hottest issue in the antibacterial activity. The induction of intracellular ROS generation can cause death and have been considered as a major ability of ZnO-NPs. Release of $\mathrm{Zn}^{2+}$ ions and adhesion on the cell membrane cause mechanical damage to the cell wall. Additionally, a brief presentation of a study conducted by authors of this review was explored. Finally, a concise discussion was given to one vital application as antimicrobial agent on food.

The importance and significance of $\mathrm{ZnO}-\mathrm{NPs}$ in various areas has developed global interest to study their antibacterial activity. The documented antibacterial actions of ZnO-NPs have stimulated a considerable range of antimicrobial applications. ZnO-NPs possess unique properties and excellent stability with long life compared with organic-based disinfectants that stimulated its use as antibacterial agent. The large surface area-to-volume ratio allows their use as novel antimicrobial agents, which are coming up as recent concern for researchers.

A goal of this review is to set a well-built reference for scientists interested in antibacterial activities along with their functional applications by considering nanotechnology principles as it relates to the nanobiological toxicity of ZnO-NPs. The noble properties and attractive characteristics of ZnO-NPs confer significant toxicity to organisms, which have made $\mathrm{ZnO}-\mathrm{NPs}$ successful candidate among other metal oxides. Other specific properties are predicted to expand $\mathrm{ZnO}-\mathrm{NPs}$ applications in several areas, particularly in catalysis and biomedicine. A number of significant breakthroughs have emerged in the areas of antimicrobial applications, as in the food industry.

This survey revealed the sensitivity of ZnO-NPs toward characteristic microorganisms that are of threatening concern. Based on the toxicity mechanism of $\mathrm{ZnO}-\mathrm{NPs}$, this review concludes that the toxicity differs from one study to another according to the test conditions, further mechanisms and researches are currently being investigated. Additional research is required to investigate the exact toxicity mechanisms to deeply elucidate the sensitivity of bacteria to $\mathrm{ZnO}-\mathrm{NPs}$, as the results to date are quite promising. However, this will necessitates further researches to adequately scrutinize the NPs properties. A possible research avenue is the combinations with other classes of antibacterial agents such as the application of $\mathrm{ZnO}$-NPs as supporter of silver NPs, which are antibacterial agents that 
contain silver as precursor. This topic is regarded as a powerful application forecast and marketable significance.

More emphasis should be given to the correlation between $\mathrm{ZnO}-\mathrm{NPs}$ structural, optical, electrical, chemical properties, and their bacterial toxicity. ZnO-NPs can act as smart weapon toward multidrug-resistant microorganisms and a talented substitute approach to antibiotics. The toxicological influence of $\mathrm{ZnO}-\mathrm{NPs}$ should be evaluated to determine the consequences of using these NPs in food safety. It is anticipated that this review may be able to enhance further research into novel methodological characterization and clinical correlations in this topic. Meanwhile, solutions would be suggested to consequences of health-related problems by addressing this complex through research and scientific reports.

Acknowledgments We acknowledge the financial support from a research university Grant number 1001/PFIZIK/814174 of Universiti Sains Malaysia (USM). Thanks are due to the Emerging Nations Science Foundation (ENSF), for the fellowship award. We are grateful to all who gave us permissions to adapt from their evaluated articles. We thank NOR Lab staff, at School of Physics for the characterization of $\mathrm{ZnO}-\mathrm{NPs}$. We gratefully appreciate the assistance of Microbiology Lab, School of Medical Sciences USM, where series of in vitro assays were conducted that emerged with this review.

Open Access This article is distributed under the terms of the Creative Commons Attribution 4.0 International License (http:// creativecommons.org/licenses/by/4.0/), which permits unrestricted use, distribution, and reproduction in any medium, provided you give appropriate credit to the original author(s) and the source, provide a link to the Creative Commons license, and indicate if changes were made.

\section{References}

1. S. Sahoo, Socio-ethical issues and nanotechnology development: perspectives from India, in 2010 10th IEEE Conference on Nanotechnology (IEEE-NANO), Seoul, South Korea, USA, 17-20 August 2010 (IEEE, 2010), pp. 1205-1210. doi:10.1109/ NANO.2010.5697887

2. V. Yadav, Nanotechnology, big things from a tiny world: a review. AEEE 3(6), 771-778 (2013)

3. S. Pal, Y.K. Tak, J.M. Song, Does the antibacterial activity of silver nanoparticles depend on the shape of the nanoparticle? A study of the gram-negative bacterium Escherichia coli. Appl. Environ. Microbiol. 73(6), 1712-1720 (2007). doi:10.1128/ AEM.02218-06

4. B. Ashe, A Detail investigation to observe the effect of zinc oxide and Silver nanoparticles in biological system, M.Sc. (Roll NO-607bm004), National Institute of Technology, 2011

5. C. Buzea, I.I. Pacheco, K. Robbie, Nanomaterials and nanoparticles: sources and toxicity. Biointerphases 2(4), MR17MR71 (2007). doi:10.1116/1.2815690

6. J.W. Rasmussen, E. Martinez, P. Louka, D.G. Wingett, Zinc oxide nanoparticles for selective destruction of tumor cells and potential for drug delivery applications. Expert Opin. Drug Deliv. 7(9), 1063-1077 (2010). doi:10.1517/17425247.2010. 502560
7. R. Brayner, R. Ferrari-Iliou, N. Brivois, S. Djediat, M.F. Benedetti, F. Fiévet, Toxicological impact studies based on Escherichia coli bacteria in ultrafine $\mathrm{ZnO}$ nanoparticles colloidal medium. Nano Lett. 6(4), 866-870 (2006). doi:10.1021/ n1052326h

8. N. Jones, B. Ray, K.T. Ranjit, A.C. Manna, Antibacterial activity of $\mathrm{ZnO}$ nanoparticle suspensions on a broad spectrum of microorganisms. FEMS Microbiol. Lett. 279(1), 71-76 (2008). doi:10.1111/j.1574-6968.2007.01012.x

9. R. Jalal, E.K. Goharshadi, M. Abareshi, M. Moosavi, A. Yousefi, P. Nancarrow, ZnO nanofluids: green synthesis, characterization, and antibacterial activity. Mater. Chem. Phys. 121(1), 198-201 (2010). doi:10.1016/j.matchemphys.2010.01. 020

10. J.T. Seil, T.J. Webster, Antimicrobial applications of nanotechnology: methods and literature. Int. J. Nanomed. 7, 27672781 (2012). doi:10.2147/IJN.S24805

11. Z. Emami-Karvani, P. Chehrazi, Antibacterial activity of $\mathrm{ZnO}$ nanoparticle on gram-positive and gram-negative bacteria. Afr. J. Microbiol. Res. 5(12), 1368-1373 (2011)

12. N. Padmavathy, R. Vijayaraghavan, Enhanced bioactivity of $\mathrm{ZnO}$ nanoparticles-an antimicrobial study. Sci. Technol. Adv. Mater. 9(3), 035004 (2008). doi:10.1088/1468-6996/9/3/035004

13. K.R. Raghupathi, R.T. Koodali, A.C. Manna, Size-dependent bacterial growth inhibition and mechanism of antibacterial activity of zinc oxide nanoparticles. Langmuir 27(7), 4020-4028 (2011). doi:10.1371/journal.pone.0085981

14. G. Colon, B.C. Ward, T.J. Webster, Increased osteoblast and decreased Staphylococcus epidermidis functions on nanophase $\mathrm{ZnO}$ and $\mathrm{TiO}_{2}$. J. Biomed. Mater. Res. 78(3), 595-604 (2006). doi:10.1002/jbm.a.30789

15. J.T. Seil, E.N. Taylor, T.J. Webster, Reduced activity of Staphylococcus epidermidis in the presence of sonicated piezoelectric zinc oxide nanoparticles, in 2009 IEEE 35th Annual Northeast Bioengineering Conference, Boston, MA, USA, 3-5 April 2009 (IEEE, 2009), pp. 1-2. doi:10.1109/NEBC.2009. 4967674

16. K. Kotloff, J. Winickoff, B. Ivanoff, J.D. Clemens, D. Swerdlow, P. Sansonetti, G. Adak, M. Levine, Global burden of Shigella infections: implications for vaccine development and implementation of control strategies. Bull. World Health Organ 77(8), 651-666 (1999)

17. Y.G. Gertrude Neumark, I. Kuskovsky, in Springer Handbook of Electronic and Photonic Materials: Doping Aspects of Zn-Based Wide-Band-Gap Semiconductors, ed. by P.C. Safa Kasap (Springer, 2007), pp. 843-854. doi:10.1007/978-0-387-291857_35

18. Z. Fan, J.G. Lu, Zinc oxide nanostructures: synthesis and properties. J. Nanosci. Nanotechnol. 5(10), 1561-1573 (2005). doi:10.1166/jnn.2005.182

19. Z.L. Wang, Zinc oxide nanostructures: growth, properties and applications. J. Phys.: Condens. Matter 16(25), R829-R858 (2004). doi:10.1088/0953-8984/16/25/R01

20. Z.L. Wang, J. Song, Piezoelectric nanogenerators based on zinc oxide nanowire arrays. Science 312(5771), 242-246 (2006). doi:10.1126/science.1124005

21. A. Janotti, C.G. Van de Walle, Fundamentals of zinc oxide as a semiconductor. Rep. Prog. Phys. 72(12), 126501 (2009). doi:10. 1088/0034-4885/72/12/126501

22. Y. Zhang, M.K. Ram, E.K. Stefanakos, D.Y. Goswami, Synthesis, characterization, and applications of $\mathrm{ZnO}$ nanowires. J. Nanomater. 2012, 1-22 (2012). doi:10.1155/2012/624520

23. L. Schmidt-Mende, J.L. MacManus-Driscoll, ZnO-nanostructures, defects, and devices. Mater. Today 10(5), 40-48 (2007). doi:10.1016/S1369-7021(07)70078-0 
24. J. Wellings, N. Chaure, S. Heavens, I. Dharmadasa, Growth and characterisation of electrodeposited $\mathrm{ZnO}$ thin films. Thin Solid Films 516(12), 3893-3898 (2008). doi:10.1016/j.tsf.2007.07.156

25. Z. Song, T.A. Kelf, W.H. Sanchez, M.S. Roberts, J. Rička, M. Frenz, A.V. Zvyagin, Characterization of optical properties of $\mathrm{ZnO}$ nanoparticles for quantitative imaging of transdermal transport. Biomed. Opt. Express 2(12), 3321-3333 (2011). doi:10.1364/BOE.2.003321

26. Y. Mishra, V. Chakravadhanula, V. Hrkac, S. Jebril, D. Agarwal, S. Mohapatra, D. Avasthi, L. Kienle, R. Adelung, Crystal growth behaviour in $\mathrm{Au}-\mathrm{ZnO}$ nanocomposite under different annealing environments and photoswitchability. J. Appl. Phys. 112(6), 064308 (2012). doi:10.1063/1.4752469

27. N. Yahya, H. Daud, N.A. Tajuddin, H.M. Daud, A. Shafie, P. Puspitasari, Application of $\mathrm{ZnO}$ nanoparticles EM wave detector prepared by sol-gel and self-combustion techniques. J. Nano Res. 11, 25-34 (2010). doi:10.4028/www.scientific.net/JNanoR. 11.25

28. S. Mahmud, One-dimensional growth of zinc oxide nanostructures from large micro-particles in a highly rapid synthesis. J. Alloys Compd. 509(9), 4035-4040 (2011). doi:10.1016/j.jall com.2011.01.013

29. J.E. Ramirez-Vick, Nanostructured $\mathrm{ZnO}$ for electrochemical biosensors. J. Biosens. Bioelectron. (2012). doi:10.4172/2155$6210.1000 \mathrm{e} 109$

30. H. Karami, E. Fakoori, Synthesis and characterization of $\mathrm{ZnO}$ nanorods based on a new gel pyrolysis method. J. Nanomater. 2011, 628203 (2011). doi: $10.1155 / 2011 / 628203$

31. Z. Xu, J.-Y. Hwang, B. Li, X. Huang, H. Wang, The characterization of various $\mathrm{ZnO}$ nanostructures using field-emission SEM. JOM 60(4), 29-32 (2008). doi:10.1007/s11837-008-00449

32. R. Wahab, S. Ansari, Y. Kim, H. Seo, G. Kim, G. Khang, H.-S. Shin, Low temperature solution synthesis and characterization of $\mathrm{ZnO}$ nano-flowers. Mater. Res. Bull. 42(9), 1640-1648 (2007). doi:10.1016/j.materresbull.2006.11.035

33. J. Zhang, L. Sun, J. Yin, H. Su, C. Liao, C. Yan, Control of ZnO morphology via a simple solution route. Chem. Mater. 14(10), 4172-4177 (2002). doi:10.1021/cm020077h

34. R. Wahab, A. Mishra, S.-I. Yun, Y.-S. Kim, H.-S. Shin, Antibacterial activity of $\mathrm{ZnO}$ nanoparticles prepared via non-hydrolytic solution route. Appl. Microbiol. Biotechnol. 87(5), 1917-1925 (2010). doi:10.1007/s00253-010-2692-2

35. R. Wahab, M.A. Siddiqui, Q. Saquib, S. Dwivedi, J. Ahmad, J. Musarrat, A.A. Al-Khedhairy, H.-S. Shin, ZnO nanoparticles induced oxidative stress and apoptosis in HepG2 and MCF-7 cancer cells and their antibacterial activity. Colloids Surf. B 117, 267-276 (2014). doi:10.1016/j.colsurfb.2014.02.038

36. A. Stanković, S. Dimitrijević, D. Uskoković, Influence of size scale and morphology on antibacterial properties of $\mathrm{ZnO}$ powders hydrothermally synthesized using different surface stabilizing agents. Colloids Surf. B 102, 21-28 (2013). doi:10.1016/j. colsurfb.2012.07.033

37. J.M. Wu, Heterojunction nanowires of $\operatorname{Ag}_{\mathrm{x}} \mathrm{Zn}_{1-\mathrm{x}} \mathrm{O}-\mathrm{ZnO}$ photocatalytic and antibacterial activities under visible-light and dark conditions. J. Phys. Chem. C 119(3), 1433-1441 (2015). doi:10.1021/jp510259j

38. J.I. Tariq Jan, M. Ismail, M. Zakaullah, S.H. Naqvi, N. Badshah, $\mathrm{Sn}$ doping induced enhancement in the activity of $\mathrm{ZnO}$ nanostructures against antibiotic resistant $S$. aureus bacteria. Int. J. Nanomed. 8(1), 3679-3687 (2013). doi:10.2147/IJN.S45439

39. V.B. Schwartz, F. Thétiot, S. Ritz, S. Pütz, L. Choritz, A. Lappas, R. Förch, K. Landfester, U. Jonas, Antibacterial surface coatings from zinc oxide nanoparticles embedded in poly $(n-$ isopropylacrylamide) hydrogel surface layers. Adv. Funct. Mater. 22(11), 2376-2386 (2012). doi:10.1002/adfm.201102980
40. L. Zhang, Y. Jiang, Y. Ding, M. Povey, D. York, Investigation into the antibacterial behaviour of suspensions of $\mathrm{ZnO}$ nanoparticles (ZnO nanofluids). J. Nanopart. Res. 9(3), 479-489 (2007). doi:10.1007/s11051-006-9150-1

41. U. Ozgur, Y.I. Alivov, C. Liu, A. Teke, M. Reshchikov, S. Dogan, V. Avrutin, S.J. Cho, H. Morkoc, A comprehensive review of $\mathrm{ZnO}$ materials and devices. J. Appl. Phys. 98(4), 041301 (2005). doi:10.1063/1.1992666

42. A. Moezzi, A.M. McDonagh, M.B. Cortie, Zinc oxide particles: synthesis, properties and applications. Chem. Eng. J. 185, 1-22 (2012). doi:10.1016/j.cej.2012.01.076

43. S. George, S. Pokhrel, T. Xia, B. Gilbert, Z. Ji, M. Schowalter, A. Rosenauer, R. Damoiseaux, K.A. Bradley, L. Mädler, Use of a rapid cytotoxicity screening approach to engineer a safer zinc oxide nanoparticle through iron doping. ACS Nano 4(1), 15-29 (2009). doi:10.1021/nn901503q

44. G. Fu, P.S. Vary, C.-T. Lin, Anatase $\mathrm{TiO}_{2}$ nanocomposites for antimicrobial coatings. J. Phys. Chem. B 109(18), 8889-8898 (2005). doi:10.1021/jp0502196

45. J.V.A. Edwards, K.J. Edwards, Bacteria Cell, http://www.alkenmurray.com/BioInfo1-05.html. Accessed 9 July 2010

46. R. Wahab, Y.-S. Kim, A. Mishra, S.-I. Yun, H.-S. Shin, Formation of $\mathrm{ZnO}$ micro-flowers prepared via solution process and their antibacterial activity. Nanoscale Res. Lett. 5(10), 16751681 (2010). doi:10.1007/s11671-010-9694-y

47. M. Premanathan, K. Karthikeyan, K. Jeyasubramanian, G. Manivannan, Selective toxicity of $\mathrm{ZnO}$ nanoparticles toward Gram-positive bacteria and cancer cells by apoptosis through lipid peroxidation. Nanomed. Nanotechnol. Biol. Med. 7(2), 184-192 (2011). doi:10.1016/j.nano.2010.10.001

48. J. Sawai, Quantitative evaluation of antibacterial activities of metallic oxide powders $(\mathrm{ZnO}, \mathrm{MgO}$ and $\mathrm{CaO})$ by conductimetric assay. J. Microbiol. Methods 54(2), 177-182 (2003). doi:10. 1016/S0167-7012(03)00037-X

49. S.O. Sukon Phanichphantand, Antimicrobial nanomaterials in the textile industry, in Bionanotechnology II Global Prospects, ed. by D.E. Reisner (CRC Press, Boca Raton, 2011), p. 2

50. K.M. Reddy, K. Feris, J. Bell, D.G. Wingett, C. Hanley, A. Punnoose, Selective toxicity of zinc oxide nanoparticles to prokaryotic and eukaryotic systems. Appl. Phys. Lett. 90(21), 213902 (2007). doi: $10.1063 / 1.2742324$

51. O. Yamamoto, Influence of particle size on the antibacterial activity of zinc oxide. Int. J. Inorg. Mater. 3(7), 643-646 (2001). doi:10.1016/S1466-6049(01)00197-0

52. S. Nair, A. Sasidharan, V.D. Rani, D. Menon, S. Nair, K. Manzoor, S. Raina, Role of size scale of $\mathrm{ZnO}$ nanoparticles and microparticles on toxicity toward bacteria and osteoblast cancer cells. J. Mater. Sci. Mater. Med. 20(1), 235-241 (2009). doi:10. 1007/s10856-008-3548-5

53. A.L. Barry, W.A. Craig, H. Nadler, L.B. Reller, C.C. Sanders, J.M. Swenson, in Methods for Determining Bactericidal Activity of Antimicrobial Agents; Approved Guideline, vol. 19, 18th edn. (National Committee for Clinical Laboratory Standards, CLSI, Wayne, 1999)

54. M. Aslam, I. Anis, N. Afza, M.T. Hussain, L. Iqbal, A. Hussain, S. Iqbal, T.H. Bokhari, M. Khalid, Synthesis, antibacterial, lipoxygenase and urease inhibitory activities of 2-aminophenol derivatives. Med. Chem. Drug Discov. 3(2), 80-86 (2012)

55. R. Prasad, D. Basavaraju, K. Rao, C. Naveen, J. Endrino, A. Phani, Nanostructured $\mathrm{TiO}_{2}$ and $\mathrm{TiO}_{2}-\mathrm{Ag}$ antimicrobial thin films, in Proceedings of the 2011 International Conference on Nanoscience, Technology and Societal Implications (NSTSI), Bhubaneswar, USA, 8-10 December 2011 (IEEE, 2011), pp. 1-6. doi:10.1109/NSTSI.2011.6111808

56. L.K. Adams, D.Y. Lyon, P.J. Alvarez, Comparative eco-toxicity of nanoscale $\mathrm{TiO}_{2}, \mathrm{SiO}_{2}$, and $\mathrm{ZnO}$ water suspensions. Water 
Res. 40(19), 3527-3532 (2006). doi:10.1016/j.watres.2006.08. 004

57. K. Kasemets, A. Ivask, H.-C. Dubourguier, A. Kahru, Toxicity of nanoparticles of $\mathrm{ZnO}, \mathrm{CuO}$ and $\mathrm{TiO}_{2}$ to yeast Saccharomyces cerevisiae. Toxicol. In Vitro 23(6), 1116-1122 (2009). doi:10. 1016/j.tiv.2009.05.015

58. T.J. Brunner, P. Wick, P. Manser, P. Spohn, R.N. Grass, L.K. Limbach, A. Bruinink, W.J. Stark, In vitro cytotoxicity of oxide nanoparticles: comparison to asbestos, silica, and the effect of particle solubility. Environ. Sci. Technol. 40(14), 4374-4381 (2006). doi:10.1021/es052069i

59. M. Li, L. Zhu, D. Lin, Toxicity of $\mathrm{ZnO}$ nanoparticles to Escherichia coli: mechanism and the influence of medium components. Environ. Sci. Technol. 45(5), 1977-1983 (2011). doi:10.1021/es102624t

60. J. Sawai, S. Shoji, H. Igarashi, A. Hashimoto, T. Kokugan, M. Shimizu, H. Kojima, Hydrogen peroxide as an antibacterial factor in zinc oxide powder slurry. J. Ferment. Bioeng. 86(5), 521-522 (1998). doi:10.1016/S0922-338X(98)80165-7

61. A. Lipovsky, Y. Nitzan, A. Gedanken, R. Lubart, Antifungal activity of $\mathrm{ZnO}$ nanoparticles - the role of ROS mediated cell injury. Nanotechnology 22(10), 105101 (2011). doi:10.1088/ 0957-4484/22/10/105101

62. L. Zhang, Y. Ding, M. Povey, D. York, ZnO nanofluids-a potential antibacterial agent. Prog. Nat. Sci. 18(8), 939-944 (2008). doi:10.1016/j.pnsc.2008.01.026

63. J. Zhang, Silver-coated zinc oxide nanoantibacterial synthesis and antibacterial activity characterization, in 2011 International Conference on Electronics and Optoelectronics (ICEOE), vol. 3 , Dalian, Liaoning, USA, 29-31 July 2011 (IEEE, 2011), pp. V394-V3-98. doi:10.1109/ICEOE.2011.6013309

64. M. Nirmala, M.G. Nair, K. Rekha, A. Anukaliani, S. Samdarshi, R.G. Nair, Photocatalytic activity of $\mathrm{ZnO}$ nanopowders synthesized by DC thermal plasma. Afr. J. Basic Appl. Sci. 2(5-6), 161-166 (2010)

65. M. E, Proceedings of the photoconductivity conference, photoconductivity conference, Atlantic City, Pennsylvania (4-6 Nov. 1956): John Wiley and Sons, Inc, New York (1956)

66. I.S.J. Bao, Z. Su, R. Gurwitz, F. Capasso, X. Wang, Z. Ren, Photoinduced oxygen release and persistent photoconductivity in $\mathrm{ZnO}$ nanowires. Nanoscale Res. Lett. 6(404), 1-7 (2011). doi:10.1186/1556-276X-6-404

67. S. Baruah, M.A. Mahmood, M.T.Z. Myint, T. Bora, J. Dutta, Enhanced visible light photocatalysis through fast crystallization of zinc oxide nanorods. Beilstein J. Nanotechnol. 1(1), 14-20 (2010). doi:10.3762/bjnano.1.3

68. H. Zhang, B. Chen, H. Jiang, C. Wang, H. Wang, X. Wang, A strategy for $\mathrm{ZnO}$ nanorod mediated multi-mode cancer treatment. Biomaterials 32(7), 1906-1914 (2011). doi:10.1016/j.bio materials.2010.11.027

69. O. Seven, B. Dindar, S. Aydemir, D. Metin, M. Ozinel, S. Icli, Solar photocatalytic disinfection of a group of bacteria and fungi aqueous suspensions with $\mathrm{TiO}_{2}, \mathrm{ZnO}$ and Sahara Desert dust. J. Photochem. Photobiol. A 165(1), 103-107 (2004). doi:10.1016/ j.jphotochem.2004.03.005

70. S. Ahmed, M. Rasul, W.N. Martens, R. Brown, M. Hashib, Heterogeneous photocatalytic degradation of phenols in wastewater: a review on current status and developments. Desalination 261(1), 3-18 (2010). doi:10.1016/j.desal.2010.04.062

71. P.J.P. Espitia, N.d.F.F. Soares, J.S. dos Reis Coimbra, N.J. de Andrade, R.S. Cruz, E.A.A. Medeiros, Zinc oxide nanoparticles: synthesis, antimicrobial activity and food packaging applications. Food Bioprocess Technol. 5(5), 1447-1464 (2012). doi:10.1007/s11947-012-0797-6

72. G. Zhou, Y. Li, W. Xiao, L. Zhang, Y. Zuo, J. Xue, J.A. Jansen, Synthesis, characterization, and antibacterial activities of a novel nanohydroxyapatite/zinc oxide complex. J. Biomed. Mater. Res. A 85(4), 929-937 (2008). doi:10.1002/jbm.a.31527

73. P. Joshi, S. Chakraborti, P. Chakrabarti, D. Haranath, V. Shanker, Z. Ansari, S.P. Singh, V. Gupta, Role of surface adsorbed anionic species in antibacterial activity of $\mathrm{ZnO}$ quantum dots against Escherichia coli. J. Nanosci. Nanotechnol. 9(11), 64276433 (2009). doi:10.1166/jnn.2009.1584

74. K. Hirota, M. Sugimoto, M. Kato, K. Tsukagoshi, T. Tanigawa, H. Sugimoto, Preparation of zinc oxide ceramics with a sustainable antibacterial activity under dark conditions. Ceram. Int. 36(2), 497-506 (2010). doi:10.1016/j.ceramint.2009.09.026

75. L.C. Ann, S. Mahmud, S.K.M. Bakhori, A. Sirelkhatim, D. Mohamad, H. Hasan, A. Seeni, R.A. Rahman, Effect of surface modification and UVA photoactivation on antibacterial bioactivity of zinc oxide powder. Appl. Surf. Sci. 292, 405-412 (2014). doi:10.1016/j.apsusc.2013.11.152

76. I.G. Kirkinezos, C.T. Moraes, Reactive oxygen species and mitochondrial diseases. Semin. Cell Dev. Biol. 12(6), 449-457 (2001). doi:10.1006/scdb.2001.0282

77. N. Talebian, S.M. Amininezhad, M. Doudi, Controllable synthesis of $\mathrm{ZnO}$ nanoparticles and their morphology-dependent antibacterial and optical properties. J. Photochem. Photobiol. 120, 66-73 (2013). doi:10.1016/j.jphotobiol.2013.01.004

78. J. Ma, J. Liu, Y. Bao, Z. Zhu, X. Wang, J. Zhang, Synthesis of largescale uniform mulberry-like $\mathrm{ZnO}$ particles with microwave hydrothermal method and its antibacterial property. Ceram. Int. 39(3), 2803-2810 (2013). doi:10.1016/j.ceramint.2012.09.049

79. M. Ramani, S. Ponnusamy, C. Muthamizhchelvan, E. Marsili, Amino acid-mediated synthesis of zinc oxide nanostructures and evaluation of their facet-dependent antimicrobial activity. Colloids Surf. B 117, 233-239 (2014). doi:10.1016/j.colsurfb.2014.02.017

80. H. Yang, C. Liu, D. Yang, H. Zhang, Z. Xi, Comparative study of cytotoxicity, oxidative stress and genotoxicity induced by four typical nanomaterials: the role of particle size, shape and composition. J. Appl. Toxicol. 29(1), 69-78 (2009). doi:10. 1002/jat. 1385

81. G. Li, T. Hu, G. Pan, T. Yan, X. Gao, H. Zhu, Morphologyfunction relationship of $\mathrm{ZnO}$ : polar planes, oxygen vacancies, and activity. J. Phys. Chem. C 112(31), 11859-11864 (2008). doi:10.1021/jp8038626

82. G.-X. Tong, F.-F. Du, Y. Liang, Q. Hu, R.-N. Wu, J.-G. Guan, $\mathrm{X}$. Hu, Polymorphous $\mathrm{ZnO}$ complex architectures: selective synthesis, mechanism, surface area and Zn-polar plane-codetermining antibacterial activity. J. Mater. Chem. B 1(4), 454463 (2013). doi:10.1039/C2TB00132B

83. L.C. Ann, S. Mahmud, S.K.M. Bakhori, A. Sirelkhatim, D. Mohamad, H. Hasan, A. Seeni, R.A. Rahman, Antibacterial responses of zinc oxide structures against Staphylococcus aureus, Pseudomonas aeruginosa and Streptococcus pyogenes. Ceram. Int. 40(2), 2993-3001 (2014). doi:10.1016/j.ceramint. 2013.10.008

84. M.H. Mamat, Z. Khusaimi, M.M. Zahidi, M.R. Mahmood, Performance of an ultraviolet photoconductive sensor using well-aligned aluminium-doped zinc-oxide nanorod arrays annealed in an air and oxygen environment. Jpn. J. Appl. Phys. 50(6), 06GF05-06GF05-4 (2011). doi:10.1143/JJAP.50.06GF05

85. Y. Leung, C. Chan, A. Ng, H. Chan, M. Chiang, A. Djurišić, Y. $\mathrm{Ng}$, W. Jim, M. Guo, F. Leung, Antibacterial activity of $\mathrm{ZnO}$ nanoparticles with a modified surface under ambient illumination. Nanotechnology 23(47), 475703 (2012). doi:10.1088/09574484/23/47/475703

86. A. Hsu, F. Liu, Y.H. Leung, A.P. Ma, A.B. Djurišić, F.C. Leung, W.K. Chan, H.K. Lee, Is the effect of surface modifying molecules on antibacterial activity universal for a given material? Nanoscale 6(17), 10323-10331 (2014). doi:10.1039/ $\mathrm{C} 4 \mathrm{NR} 02366 \mathrm{H}$ 
87. X. Peng, S. Palma, N.S. Fisher, S.S. Wong, Effect of morphology of $\mathrm{ZnO}$ nanostructures on their toxicity to marine algae. Aquat. Toxicol. 102(3), 186-196 (2011). doi:10.1016/j.aquatox. 2011.01.014

88. J. Sawai, E. Kawada, F. Kanou, H. Igarashi, A. Hashimoto, T. Kokugan, M. Shimizu, Detection of active oxygen generated from ceramic powders having antibacterial activity. J. Chem. Eng. Jpn. 29(4), 627-633 (1996). doi:10.1252/jcej.29.627

89. N.M. Franklin, N.J. Rogers, S.C. Apte, G.E. Batley, G.E. Gadd, P.S. Casey, Comparative toxicity of nanoparticulate $\mathrm{ZnO}$, bulk $\mathrm{ZnO}$, and $\mathrm{ZnCl}_{2}$ to a freshwater microalga (Pseudokirchneriella subcapitata): the importance of particle solubility. Environ. Sci. Technol. 41(24), 8484-8490 (2007). doi:10.1021/es071445r

90. H.A. Jeng, J. Swanson, Toxicity of metal oxide nanoparticles in mammalian cells. J. Environ. Sci. Health. A 41(12), 2699-2711 (2006). doi:10.1080/10934520600966177

91. Y. Xie, Y. He, P.L. Irwin, T. Jin, X. Shi, Antibacterial activity and mechanism of action of zinc oxide nanoparticles against Campylobacter jejuni. Appl. Environ. Microbiol. 77(7), 23252331 (2011). doi:10.1128/AEM.02149-10

92. L. Palanikumar, S.N. Ramasamy, C. Balachandran, Size-dependent antimicrobial response of zinc oxide nanoparticles. IET Nanobiotechnol. 8(2), 111-117 (2014)

93. S. Atmaca, K. Gül, R. Cicek, The effect of zinc on microbial growth. Turk. J. Med. Sci. 28(6), 595-598 (1998)

94. H. Hu, W. Zhang, Y. Qiao, X. Jiang, X. Liu, C. Ding, Antibacterial activity and increased bone marrow stem cell functions of $\mathrm{Zn}$-incorporated $\mathrm{TiO}_{2}$ coatings on titanium. Acta Biomater. 8(2), 904-915 (2012). doi:10.1016/j.actbio.2011.09.031

95. W. Salem, D.R. Leitner, F.G. Zingl, G. Schratter, R. Prassl, W. Goessler, J. Reidl, S. Schild, Antibacterial activity of silver and zinc nanoparticles against Vibrio cholerae and enterotoxic Escherichia coli. Int. J. Med. Microbiol. 305(1), 85-95 (2015). doi:10.1016/j.ijmm.2014.11.005

96. F. Kroger, The Chemistry of Imperfect Crystals. Vol. 2. Imperfection Chemistry of Crystalline Solids (Elsevier, New York, 1974)

97. X. Wang, F. Yang, W. Yang, X. Yang, A study on the antibacterial activity of one-dimensional $\mathrm{ZnO}$ nanowire arrays: effects of the orientation and plane surface. Chem. Commun. 42, 4419-4421 (2007). doi:10.1039/b708662h

98. K. Tam, A. Djurišić, C. Chan, Y. Xi, C. Tse, Y. Leung, W. Chan, F. Leung, D. Au, Antibacterial activity of $\mathrm{ZnO}$ nanorods prepared by a hydrothermal method. Thin Solid Films 516(18), 6167-6174 (2008). doi:10.1016/j.tsf.2007.11.081

99. R. Karmali, A. Bartakke, V. Borker, K. Rane, Bactericidal action of $\mathrm{N}$ doped $\mathrm{ZnO}$ in sunlight. Biointerface Res. Appl. Chem. 1(2), 57-63 (2011)

100. P.K. Stoimenov, R.L. Klinger, G.L. Marchin, K.J. Klabunde, Metal oxide nanoparticles as bactericidal agents. Langmuir 18(17), 6679-6686 (2002). doi:10.1021/la0202374

101. J.S. Kim, E. Kuk, K.N. Yu, J.-H. Kim, S.J. Park, H.J. Lee, S.H. Kim, Y.K. Park, Y.H. Park, C.-Y. Hwang, Antimicrobial effects of silver nanoparticles. Nanomed. Nanotechnol. Biol. Med. 3(1), 95-101 (2007). doi:10.1016/j.nano.2006.12.001

102. L. Liu, J. Yang, J. Xie, Z. Luo, J. Jiang, Y.Y. Yang, S. Liu, The potent antimicrobial properties of cell penetrating peptide-conjugated silver nanoparticles with excellent selectivity for Grampositive bacteria over erythrocytes. Nanoscale 5(9), 3834-3840 (2013). doi:10.1039/c3nr34254a

103. J.Y. Kim, J.Y. Yoon, Developing a testing method for antimicrobial efficacy on $\mathrm{TiO}_{2}$ photocatalytic products. Environ. Eng. Res. 13(3), 136-140 (2008). doi:10.4491/eer.2008.13.3.136

104. I.-L. Hsiao, Y.-J. Huang, Effects of various physicochemical characteristics on the toxicities of $\mathrm{ZnO}$ and $\mathrm{TiO}_{2}$ nanoparticles toward human lung epithelial cells. Sci. Total Environ. 409(7), 1219-1228 (2011). doi:10.1016/j.scitotenv.2010.12.033
105. H. Zhang, X. Lv, Y. Li, Y. Wang, J. Li, P25-graphene composite as a high performance photocatalyst. ACS Nano 4(1), 380-386 (2009). doi:10.1021/nn901221k

106. Z. Huang, X. Zheng, D. Yan, G. Yin, X. Liao, Y. Kang, Y. Yao, D. Huang, B. Hao, Toxicological effect of $\mathrm{ZnO}$ nanoparticles based on bacteria. Langmuir 24(8), 4140-4144 (2008). doi:10. 1021/la7035949

107. T. Xia, M. Kovochich, M. Liong, L. Mädler, B. Gilbert, H. Shi, J.I. Yeh, J.I. Zink, A.E. Nel, Comparison of the mechanism of toxicity of zinc oxide and cerium oxide nanoparticles based on dissolution and oxidative stress properties. ACS Nano 2(10), 2121-2134 (2008). doi:10.1021/nn800511k

108. R. Prasad, D. Basavaraju, K. Rao, C. Naveen, J. Endrino, A. Phani, Nanostructured $\mathrm{TiO}_{2}$ and $\mathrm{TiO}_{2}-\mathrm{Ag}$ antimicrobial thin films, in 2011 International Conference on Nanoscience, Technology and Societal Implications (NSTSI), Bhubaneswar, USA, 8-10 December 2011 (IEEE, 2011), pp. 1-6. doi:10.1109/ NSTSI.2011.6111808

109. S. Dwivedi, R. Wahab, F. Khan, Y.K. Mishra, J. Musarrat, A.A. Al-Khedhairy, Reactive oxygen species mediated bacterial biofilm inhibition via zinc oxide nanoparticles and their statistical determination. PLoS ONE 9(11), e111289 (2014). doi:10. 1371/journal.pone.0111289

110. W. Song, J. Zhang, J. Guo, J. Zhang, F. Ding, L. Li, Z. Sun, Role of the dissolved zinc ion and reactive oxygen species in cytotoxicity of $\mathrm{ZnO}$ nanoparticles. Toxicol. Lett. 199(3), 389-397 (2010). doi:10.1016/j.toxlet.2010.10.003

111. B. Kalyanaraman, V. Darley-Usmar, K.J. Davies, P.A. Dennery, H.J. Forman, M.B. Grisham, G.E. Mann, K. Moore, L.J. Roberts, H. Ischiropoulos, Measuring reactive oxygen and nitrogen species with fluorescent probes: challenges and limitations. Free Radic. Biol. Med. 52(1), 1-6 (2012). doi:10.1016/j. freeradbiomed.2011.09.030

112. D. Guo, H. Bi, B. Liu, Q. Wu, D. Wag, Y. Cui, Reactive oxygen species-induced cytotoxic effects of zinc oxide nanoparticles in rat retinal ganglion cells. Toxicol. In Vitro 27(2), 731-738 (2012). doi:10.1016/j.tiv.2012.12.001

113. R. Wahab, N.K. Kaushik, N. Kaushik, E.H. Choi, A. Umar, S. Dwivedi, J. Musarrat, A.A. Al-Khedhairy, ZnO nanoparticles induces cell death in malignant human $\mathrm{T} 98 \mathrm{G}$ gliomas, $\mathrm{KB}$ and non-malignant HEK cells. J. Biomed. Nanotechnol. 9(7), 1181-1189 (2013)

114. Y. Matsumura, K. Yoshikata, S.-I. Kunisaki, T. Tsuchido, Mode of bactericidal action of silver zeolite and its comparison with that of silver nitrate. Appl. Environ. Microbiol. 69(7), 42784281 (2003). doi:10.1128/AEM.69.7.4278-4281.2003

115. K.R. Messner, J.A. Imlay, The identification of primary sites of superoxide and hydrogen peroxide formation in the aerobic respiratory chain and sulfite reductase complex of Escherichia coli. J. Biol. Chem. 274(15), 10119-10128 (1999). doi:10.1074/ jbc.274.15.10119

116. L. Yuan, Y. Wang, J. Wang, H. Xiao, X. Liu, Additive effect of zinc oxide nanoparticles and isoorientin on apoptosis in human hepatoma cell line. Toxicol. Lett. 225(2), 294-304 (2014). doi:10.1016/j.toxlet.2013.12.015

117. M. Heinlaan, A. Ivask, I. Blinova, H.-C. Dubourguier, A. Kahru, Toxicity of nanosized and bulk $\mathrm{ZnO}, \mathrm{CuO}$ and $\mathrm{TiO}_{2}$ to bacteria Vibrio fischeri and crustaceans Daphnia magna and Thamnocephalus platyurus. Chemosphere 71(7), 1308-1316 (2008). doi:10.1016/j.chemosphere.2007.11.047

118. B. Aydin Sevinç, L. Hanley, Antibacterial activity of dental composites containing zinc oxide nanoparticles. J. Biomed. Mater. Res. B 94(1), 22-31 (2010). doi:10.1002/jbm.b.31620

119. S.W. Wong, P.T. Leung, A. Djurišić, K.M. Leung, Toxicities of nano zinc oxide to five marine organisms: influences of aggregate size and ion solubility. Anal. Bioanal. Chem. 396(2), 609618 (2010). doi:10.1007/s00216-009-3249-z 
120. B. Wu, Y. Wang, Y.-H. Lee, A. Horst, Z. Wang, D.-R. Chen, R. Sureshkumar, Y.J. Tang, Comparative eco-toxicities of nano$\mathrm{ZnO}$ particles under aquatic and aerosol exposure modes. Environ. Sci. Technol. 44(4), 1484-1489 (2010). doi:10.1021/ es9030497

121. W. Jiang, H. Mashayekhi, B. Xing, Bacterial toxicity comparison between nano- and micro-scaled oxide particles. Environ. Pollut. 157(5), 1619-1625 (2009). doi:10.1016/j.envpol.2008. 12.025

122. J. Pasquet, Y. Chevalier, J. Pelletier, E. Couval, D. Bouvier, M.A. Bolzinger, The contribution of zinc ions to the antimicrobial activity of zinc oxide. Colloids Surf. A 457, 263-274 (2014). doi:10.1016/j.colsurfa.2014.05.057

123. X. Wang, H.-F. Wu, Q. Kuang, R.-B. Huang, Z.-X. Xie, L.-S. Zheng, Shape-dependent antibacterial activities of $\mathrm{Ag}_{2} \mathrm{O}$ polyhedral particles. Langmuir 26(4), 2774-2778 (2009). doi:10. 1021/la9028172

124. O. Yamamoto, M. Komatsu, J. Sawai, Z.-E. Nakagawa, Effect of lattice constant of zinc oxide on antibacterial characteristics. J. Mater. Sci. Mater. Med. 15(8), 847-851 (2004). doi:10.1023/ B:JMSM.0000036271.35440.36

125. L.V. Ana Stanković, S. Marković, S. Dimitrijević, S.D. Škapin, D. Uskoković, Morphology Controlled hydrothermal synthesis of $\mathrm{ZnO}$ particles and examination of their antibacterial properties on Escherichia coli and Staphylococcus aureus bacterial cultures, in Tenth Young Researchers' Conference-Materials Science and Engineering, Belgrade, Serbia, 21-23 December 2011 (Institute of Technical Sciences of SASA, Belgrade, 2011), p. 62

126. V. Berry, A. Gole, S. Kundu, C.J. Murphy, R.F. Saraf, Deposition of CTAB-terminated nanorods on bacteria to form highly conducting hybrid systems. J. Am. Chem. Soc. 127(50), 1760017601 (2005). doi:10.1021/ja0564281

127. A. Lipovsky, Z. Tzitrinovich, H. Friedmann, G. Applerot, A. Gedanken, R. Lubart, EPR study of visible light-induced ROS generation by nanoparticles of $\mathrm{ZnO}$. J. Phys. Chem. C 113(36), 15997-16001 (2009). doi:10.1021/jp904864g

128. J. Díaz-Visurraga, C. Gutiérrez, C. Von Plessing, A. García, in Science and Technology Against Microbial Pathogens Communicating Current Research and Technological Advances: Metal Nanostructures as Antibacterial Agents, ed. by A. Méndez-Vilas (Formatex, Badajoz, 2011), pp. 210-218

129. M. Ramani, S. Ponnusamy, C. Muthamizhchelvan, From zinc oxide nanoparticles to microflowers: a study of growth kinetics and biocidal activity. Mater. Sci. Eng. C 32(8), 2381-2389 (2012). doi:10.1016/j.msec.2012.07.011

130. C.-N. Lok, C.-M. Ho, R. Chen, Q.-Y. He, W.-Y. Yu, H. Sun, P.K.-H. Tam, J.-F. Chiu, C.-M. Che, Proteomic analysis of the mode of antibacterial action of silver nanoparticles. J. Proteome Res. 5(4), 916-924 (2006). doi:10.1021/pr0504079

131. H. Meruvu, M. Vangalapati, S.C. Chippada, S.R. Bammidi, Synthesis and characterization of zinc oxide nanoparticles and its antimicrobial activity against Bacillus subtilis and Escherichia coli. J. Rasayan Chem. 4(1), 217-222 (2011)

132. N.A. Amro, L.P. Kotra, K. Wadu-Mesthrige, A. Bulychev, S. Mobashery, G.-Y. Liu, High-resolution atomic force microscopy studies of the Escherichia coli outer membrane: structural basis for permeability. Langmuir 16(6), 2789-2796 (2000). doi:10. $1021 / 1 a 991013 x$
133. M.L.M. Francisco Javier Gutiérrez, P. Gatón, R. Rojo, in Scientific, Health and Social Aspects of the Food Industry: Nanotechnology and Food Industry, ed. by B. Valdez (InTech Europe, Rijeka, 2012), pp. 95-128. doi:10.5772/1869

134. Q. Chaudhry, L. Castle, Food applications of nanotechnologies: an overview of opportunities and challenges for developing countries. Trends Food Sci. Technol. 22(11), 595-603 (2011). doi:10.1016/j.tifs.2011.01.001

135. C. Silvestre, D. Duraccio, S. Cimmino, Food packaging based on polymer nanomaterials. Prog. Polym. Sci. 36(12), 1766-1782 (2011). doi:10.1016/j.progpolymsci.2011.02.003

136. T.V. Duncan, Applications of nanotechnology in food packaging and food safety: barrier materials, antimicrobials and sensors. J. Colloid Interface Sci. 363(1), 1-24 (2011). doi:10.1016/j.jcis. 2011.07.017

137. P. Kaur, R. Thakur, S. Kumar, N. Dilbaghi, Interaction of ZnO nanoparticles with food borne pathogens Escherichia coli DH5 $\alpha$ and Staphylococcus aureus 5021 and their bactericidal efficacy, in International Conference on Advances in Condensed and Nano Materials (ICACNM-2011): AIP Proceedings, Chandigarh, India, 23-26 February 2011 (2011), p. 153. doi:10.1063/1. 3653655

138. P. Narayanan, W.S. Wilson, A.T. Abraham, M. Sevanan, Synthesis, characterization, and antimicrobial activity of zinc oxide nanoparticles against human pathogens. BioNanoScience 2(4), 329-335 (2012). doi:10.1007/s12668-012-0061-6

139. K. Chitra, G. Annadurai, Antimicrobial activity of wet chemically engineered spherical shaped $\mathrm{ZnO}$ nanoparticles on food borne pathogen. Int. Food Res. J. 20(1), 59-64 (2013)

140. B. Yalcin, S. Otles, Intelligent food packaging, http://www.log forum.net/vol4/issue4/no3. Accessed 13 Feb 2008

141. H. de Azeredo, Antimicrobial nanostructures in food packaging. Trends Food Sci. Technol. 30(1), 56-69 (2013). doi:10.1016/j. tifs.2012.11.006

142. N. Soares, C.A.S. Silva, P. Santiago-Silva, P.J.P Espitia, M.P.J.C. Gonçalves, M.J.G. Lopez, J. Miltz, M.A. Cerqueira, A.A. Vicente, J. Teixeira, in Engineering Aspects of Milk and Dairy Products: Active and Intelligent Packaging for Milk and Milk Products, ed. by J.A.T. Jane Selia dos Reis Coimbra (CRC Press, 2009), pp. 155-174. doi:10.1201/9781420090390-c8

143. R. Ahvenainen (ed.), Novel Food Packaging Techniques (CRC Press, Boca Raton, 2003)

144. N.D. Kruijf, M.V. Beest, R. Rijk, T. Sipiläinen-Malm, P.P. Losada, B.D. Meulenaer, Active and intelligent packaging: applications and regulatory aspects. Food Addit. Contam. 19(S1), 144-162 (2002). doi:10.1080/02652030110072722

145. K.L. Yam, P.T. Takhistov, J. Miltz, Intelligent packaging: concepts and applications. J. Food Sci. 70(1), R1-R10 (2005). doi:10.1111/j.1365-2621.2005.tb09052.x

146. S.S. Kumar, P. Venkateswarlu, V.R. Rao, G.N. Rao, Synthesis, characterization and optical properties of zinc oxide nanoparticles. Int. Nano. Lett. 3(1), 1-6 (2013)

147. E.E. Hafez, H.S. Hassan, M. Elkady, E. Salama, Assessment Of antibacterial activity for synthesized zinc oxide nanorods against plant pathogenic strains. Int. J. Sci. Tech. Res. (IJSTR), 3(9), 318-324 (2014) 